\title{
The CEO Horizon Problem and Managerial Slack in China
}

\author{
Junxiong Fang, ${ }^{1}$ Lerong He, ${ }^{2,3}$ and Martin J. Conyon ${ }^{4}$ \\ ${ }^{1}$ Fudan University, China, ${ }^{2}$ The College at Brockport, State University of New York, USA, ${ }^{3}$ Fuzhou \\ University, China, and ${ }^{4}$ Bentley University, USA
}

\begin{abstract}
This study investigates how CEO behavior and incentives change during the CEO's final years in office, known as the horizon problem. We examine how the horizon problem alters managerial slack, a measure of operational inefficiency and managerial value diversion. Using data on Chinese publicly traded firms between 2003 and 2011, we find that managerial slack increases in the last two years of CEO tenure compared to earlier years. We also show that the increase in managerial slack in CEO final years in office is smaller in privately controlled firms than in state-owned enterprises, smaller in firms with CEO equity ownership and more independent boards compared to those without. We conclude that higher quality corporate governance mechanisms ameliorate the perverse incentives associated with the CEO horizon problem, and reduce CEOs' tendency to increase managerial slack during their final years in office.
\end{abstract}

KEYwords CEO turnover, China, corporate governance, horizon problem, slack

\section{INTRODUGTION}

A fundamental conflict between managers and shareholders is that managers' decision horizons are often shorter than shareholders' investment horizons. Because managers overvalue immediate short-term outcomes and paybacks relative to long-term results, they tend to make more conservative strategic choices and underinvest in $\mathrm{R} \& \mathrm{D}$, new technologies, durable assets, and projects with deferred payoffs (Martin, Wiseman, \& Gomez-Mejia, 2016; Matta \& Beamish, 2008; Souder \& Shaver, 2010). Such myopic decisions guided by managers' personal intertemporal preferences, while being optimal from a managerial perspective, may turn out to be suboptimal for their organizations (Laverty, 1996; Miller, 2002). As a result, managerial short-termism gives rises to the agency problem when managers sacrifice long-term interests of shareholders to seek their own short-term private gains (Fama, 1980; Jensen, 1986). 
The problem of managerial short-termism may intensify when managers approach their retirement or are about to leave their organizations (i.e., job separations). Because managers' decision horizon is constrained by their expected tenure within the organization, the 'no tomorrow' feature of the employment contract will incentivize managers to engage in opportunistic and myopic activities (Conyon \& Florou, 2006; Dechow \& Sloan, 1991). Extant research has documented that departing executives tend to reduce R\&D spending (Bebchuk \& Stole, 1993; Gibbons \& Murphy, 1992), decrease advertising and capital investment (Dechow \& Sloan, 1991), avoid risky strategies such as investing in radical innovation (Xu \& Yan, 2014) and conducting international acquisition (Matta \& Beamish, 2008), or engage in unethical earnings management to boost short-term profits (Antia, Pantzalis, \& Park, 2010). These phenomena are often labeled as 'the horizon problem' (Hambrick \& Mason, 1984).

Most research on the horizon problem is built on the premise of asymmetric and incomplete information between corporate managers and external stakeholders (Fama, 1980). Because the managerial labor market rewards executives based on their abilities assessed through near-term firm performance, managers have incentives to select projects with high near-term returns, cut down expenditure, or use accounting accruals to artificially boost short-term earnings so as to improve the labor market evaluation of their value and to increase their personal payoffs in their current positions as well as subsequent job opportunities after turnover or retirement (Brickley, Linck, \& Coles, 1999; Narayanan, 1987). Departing managers may also obtain private benefits by shirking their duties or directly diverting firm resources for personal gain (Bebchuk \& Jolls, 1999). Lott (1990), for example, documents that politicians who are about to leave office are associated with worse attendance rates and increased shirking. Managerial shirking and value diversion, however, are rarely examined in the extant literature. The primary reason is that managers cannot easily engage in blatant shirking or apparent selfdealing without being penalized in most advanced economies with sophisticated corporate governance mechanisms. The presence of the 'ex post settling-up' logic in the executive labor market indicates that the market will eventually recognize and penalize managerial shirking and wrongdoings, and thus lessens managers' incentives to engage in such behaviors (Fama, 1980).

However, the efficient market premise may not always prevail, particularly in an emerging economy with institutional voids. Many firms in emerging countries do not have effective internal and external corporate governance systems in place to successfully detect, penalize, and subsequently discourage managerial shirking and value diversion. In addition, the managerial labor market in these countries often is incapable of properly accessing and rewarding executives based on their performance (He, Shaw, \& Fang, 2017). In these circumstances, managerial shirking and value diversion may be prevalent if the departing manager's shortterm gains from shirking or self-dealing considerably outweigh long-term penalties imposed by the managerial labor market (Cai, Fang, \& $\mathrm{Xu}, 2011$ ). This type 
of managerial opportunism may impose an even larger loss for shareholders than the situation examined in prior literature when managers trade off longterm benefits for short-term gains, since shareholders do not even benefit in the short-run, let alone long-term, in this case. The main objective of our article, therefore, is to explicitly investigate whether the horizon problem will result in accentuated managerial shirking and value diversion in an emerging economy context, an important research question yet to be addressed by existing literature. We argue that short-term orientation triggered by the horizon effect when the CEO approaches job separation may cause the CEO to shirk or to divert more firm resources due to the lack of long-term accountability and effective monitoring, which in turn escalates operational inefficiency and the level of managerial slack (Williamson, 1991). Our article thus significantly extends the scope of prior literature on the horizon problem that has largely focused on performance outcomes to study a novel and important process variable, namely operational efficiency as reflected by the level of managerial slack.

In this article, managerial slack is defined as a reflection of wasteful corporate practices including excess expenditure, lax management, and overinvestment (Jensen, 1986, 1993). Managerial slack promotes personal utility of managers at the expense of shareholders, thus it is an indicator of organizational inefficiency and a deviation from profit maximization (Williamson, 1964, 1991). Although popular in the economics and finance literature, this concept stands in sharp contrast with the view of management scholars who typically consider slack as excess resources for organizational changes (Cyert \& March, 1963; March \& Simon, 1958). From this viewpoint, organizations with abundant slack are more likely to support resource consuming activities such as innovation and new strategic initiatives, while those with little slack are substantially restricted in terms of flexibility and the range of available options (Cheng \& Kesner, 1997; Singh, 1986). Generally speaking, both camps agree that slack is an excess resource that can be spent at the discretion of management, but they disagree about whether or not slack resources will be expended wisely to enhance firm value or abused by managers to increase their private benefits. To reconcile these two contrasting perspectives, and to isolate operational inefficiency and managerial private benefits from legitimate and value-enhancing expenditure in slack, we also make an important methodological contribution to the literature by utilizing a statistical residual method to identify managerial slack as deviations from the optimal slack level that is constructed based on economic fundamentals. We examine two fundamental research questions: First, is there a spike in managerial slack right before the CEO departure? Second, is the horizon effect manifested through managerial slack mitigated by more robust corporate governance arrangements?

Our research is conducted in China, an important transition economy. In spite of the rapid development of China's equity market and its pivotal role in world economy, investor protection is still significantly weaker in China compared to more advanced economies (Shen, Zhou, \& Lau, 2016). Compared to their western 
counterparts, Chinese executives have considerably more latitude to engage in excessive consumption of firm resources for their private interests that they would not be able to have if shareholders were powerful or institutions were better designed to prevent managerial opportunism (Cai et al., 2011; Gul, Cheng, \& Leung, 2011). This specific institutional context and its effect on managerial motivation and decision-making thus provide us a unique opportunity to unearth consequences of the horizon effect on managerial slack.

Davis (2005) suggests that the most relevant and promising corporate governance research should seek to understand the institutional context in which it occurs. This is particularly viable for firms having to comply with a constantly changing institutional environment in transitional economies (Peng, 2003; Wright, Filatotchev, Hoskisson, \& Peng, 2005). We thereby employ an institution-based contingency framework to examine how context-specific situational factors may affect managerial motivations and choices, and subsequently influence the magnitude of the horizon problem and its impact on managerial slack during institutional transition. Our study considers diverse ownership structures of Chinese listed firms that affect the degree of shareholder protection (Shleifer \& Vishny, 1997). We also incorporate major corporate governance reforms in executive compensation design and board structure occurring in our sample period. The utilization of these contingencies enables our study to provide a more comprehensive theoretical explanation and empirical examination of the horizon problem during institutional transition, thus extends beyond prior studies that have relied on data of developed economies with more efficient market infrastructures, more mature managerial labor markets, and more stable and sophisticated corporate governance systems (e.g., Barker \& Mueller, 2002; Matejka, Merchant, \& Stede, 2009; McClelland, Barker III, \& Oh, 2012).

\section{HYPOTHESES DEVELOPMENT AND INSTITUTIONAL BAGKGROUND}

\section{Managerial Slack and the Horizon Problem}

Williamson's (1964) theoretical model defines managerial slack as excess costs, staff, and compensation consumed by management at their own discretion. Specifically, managers may increase their personal utility by adding extra organizational staff, by consuming non-essential perquisites such as lavishly furnished offices, luxurious cars, private jets, or large expense accounts, and by making discretionary investments on pet projects, as well as by shirking on their jobs (Jensen, 1986, 1993). From this perspective, excess managerial slack becomes an agency problem, since it contributes to managerial utility at the cost of shareholder value. The potential misappropriation of firm resources for individual usage is particularly severe in China given its weak institutional environment and nascent financial reporting systems to protect shareholder interests (Shen et al., 
2016; Su, Xu, \& Phan, 2008). Cai et al. (2011), for example, observe that Chinese executives have a lot of 'grease money' at their discretion to serve their private interests. In particular, publicly traded Chinese firms are not required to disclose detailed selling and general administrative expenses (SG\&A) as they are in more advanced economies. Items such as business travel expenses, business entertainment expenses, business supply expenses, and company vehicle expenses thus can all be disguised in an aggregated number (Gul et al., 2011). Even for firms that have chosen to voluntarily report spending on these categories, the disclosure is often in a lump-sum format, which makes it extremely difficult for corporate boards and internal and external auditors to distinguish between legitimate business expenses and managerial excess. In addition, although all business expenses require receipts for reimbursement, accounting practices in China are rather inexact and managers may be reimbursed for almost any kind of entertainment and travel expenditure for any purpose, sometimes even with fake or inflated receipts (Cai et al., 2011). Such practices create significant information asymmetries between managers and shareholders, thus pose a major challenge for shareholders to protect their interests from managerial opportunism (Luo, Zhang, \& Zhu, 2011).

The use of slack to divert firm resources to serve personal benefits may become more severe during executives' final years in office. Because managers' decision horizons are shorter than those of shareholders, managers tend to pursue shortterm gains that serve their own interests at the expense of long-term benefits that are optimal for shareholders (Laverty, 1996). Such a temporal myopia problem is intensified when managers are about to leave the firm. When the managers' control of firm resources is coming to an end with the termination of their employment contracts, their incentives to promote shareholder value also diminish (Dechow \& Sloan, 1991). In essence, because managers care less about the consequences of their decisions on firm value after their departure, they have a larger tendency to engage in opportunistic self-dealing activities to achieve short-term gains at the expense of shareholders (Casamatta \& Guemel, 2010).

Previous empirical studies show that departing executives often make decisions that are not in the best interest of shareholders, including making investments that boost current earnings at the expense of future earnings (Murphy \& Zimmerman, 1993), reducing beneficial long-term R\&D spending (Bebchuk \& Stole, 1993), cutting down valuable advertising and capital expenses (Dechow \& Sloan, 1991), engaging in earnings management to increase short-term profits (Antia et al., 2010; Huson, Tian, Wiedman, \& Wier, 2012), or refraining from beneficial international acquisitions or other investments (Matta \& Beamish, 2008). Since the horizon problem may intensify and accentuate self-serving behavior of the departing executive, we argue that it will lead to a spike in managerial slack in a CEOs' final years in office either as a result of excess consumption of firm resources or lack of effective control due to job shirking. This gives rise to the following hypothesis: 
Hypothesis 1: Managerial slack will be higher in the CEO's final years in office compared to earlier years.

\section{Corporate Governance and Managerial Slack}

Slack may not always be detrimental to firm value. As March and Simon (1958: 187) explicitly note, 'when an organization has slack money or manpower not committed to ongoing programs, various specializations of function may arise with respect to commitment to new programs and program elaboration'. The thrust of this argument is that innovation and corporate change require and consume resources. Organizations with abundant slack are thus more likely to support these activities, while those without it could not afford to do so (Cheng \& Kesner, 1997; Singh, 1986). This viewpoint emphasizes the performance enhancing role of slack and presumes that managers are intrinsically motivated to care about shareholder interests. From the perspective of agency theory, whether self-interested managers will deploy slack wisely to maximize shareholder value or misappropriate it to withdraw private benefits is dependent on the presence of corporate governance mechanisms to monitor managerial activities and to constrain their opportunism (Jensen, 1993). We then proceed to discuss whether corporate governance mechanisms will mitigate the impact of the horizon effect on managerial slack.

A unique characteristic of the Chinese stock market is that a significant proportion of listed firms are State Owned Enterprises (SOEs), in which the State still retains sufficient shares and control (Delios, Wu, \& Zhou, 2006; Haveman \& Wang, 2013). This characteristic can be traced back to the original intent of the Chinese public exchange markets, which were established in the early 1990s as a vehicle to help SOEs raise much-needed financial capital. Consequently, the Chinese capital market demonstrates a significant bias in favour of SOEs over non-SOEs for a long period of time (Ding, Zhang, \& Zhang, 2007). Although SOEs are nominally owned by citizens of the country, they are actually controlled by politicians or by managers appointed by politicians through political processes. These politician managers typically have very low incentives and limited capabilities to monitor their firms because their personal interests and career reputation are far less linked to firm performance compared to their private counterparts (Chang \& Wong, 2009; Li, Xia, Long, \& Tan, 2012). In addition, maximizing shareholder value may not be the ultimate goal of SOEs who often pursue other social and political objectives such as providing employment and maintaining social stability (Stan, Peng, \& Bruton, 2014). Consequently, the extant Chinese corporate governance literature has argued that state ownership weakens investor protection, and SOEs possess lower corporate governance quality and severer agency conflicts than their privately controlled counterparts. For example, compared to privately controlled firms, Chinese SOEs are associated with a smaller CEO pay-for-performance sensitivity (Conyon \& He, 2011; Firth, Fung, \& Rui, 
2006), a smaller and often insignificant relationship between CEO turnover and firm performance (Conyon \& He, 2012; Kato \& Long, 2006; Shen \& Lin, 2009), and are less likely to penalize executives for corporate fraud either in terms of dismissal or compensation reduction (Chen, Cumming, Hou, \& Lee, 2016; Conyon \& He, 2016). Because the executive labor market is less sensitive to firm performance and managerial misconduct when evaluating SOE managers, SOE managers' future career opportunities and other long-term payoffs are less likely to be affected by these factors, which exaggerates their short-term orientation. As a result, we expect that the $\mathrm{CEO}$ horizon problem will be more serious in SOEs.

Pertinent to organizational slack, Stan et al. (2014) contend that SOEs are far less efficient in utilizing firm resources than privately controlled firms. This is first due to the fact that SOEs are often sheltered from the market as a result of soft budget constraints, i.e., they will typically be bailed out by the government with subsidies, additional bank loans, and other financial support in the event of financial distress instead of going bankrupt or being taken over (Kornari, Maskin, \& Roland, 2003). SOEs may also enjoy specific protection in certain industries where government regulations set high entry barriers for potential entrants. Limited product-market competition in these industries thus provides low incentives for SOE managers to improve operational efficiency (Hermalin, 1992; Scharfstein, 1988). In other words, the lack of market for corporate control mechanisms to discipline SOE managers leads to larger abuse of organizational slack for these managers to obtain private benefit (Hart, 1983; Stan et al., 2014). Finally, SOEs often possess worse internal control systems compared to privately controlled firms. As a result, they are unable to impose more stringent reimbursement policies to better discern and subsequently discourage illegitimate business expenditure, and to curtail unwarranted travel and entertainment expenses as well as other excessive consumption of firm resources (Feng, Li, \& McVay, 2009). Taken together, we expect that SOEs are not only more vulnerable to the CEO horizon problem, departing SOE managers are also more likely to exploit managerial slack to obtain personal gains compared to their private counterparts. We thereby make the following prediction:

Hypothesis 2: The increase of managerial slack in the CEO's final years in office will be larger in SOEs compared to those in non-SOEs.

Agency theory suggests that managerial equity ownership is an important mechanism to align managerial interests with those of shareholders and to ameliorate agency problems (Jensen \& Meckling, 1976; Jensen \& Murphy, 1990). CEOs with a high equity stake in their companies have strong incentives to operate efficiently and to promote activities that increase firm value, precisely because this increases the value of their own share-based investments (Jensen \& Warner, 1988). In contrast, CEOs with small or no equity ownership are much less motivated to diligently perform their tasks and also bear little cost when diverting firm resources, since a reduction in firm value only has a minor impact on their personal wealth. 
CEO equity ownership has been traditionally low in Chinese listed firms, but has experienced a noticeable increase in recent years. For instance, Conyon and $\mathrm{He}$ (2012) document that only about one-fifth of public company CEOs owned shares of their firms in 2005, and this figure has gradually risen to about $30 \%$ in 2010. Such an increase is mainly due to two reasons. On the one hand, considerably more privately controlled companies are now listed in the Chinese stock market. Many founders who own a significant proportion of their firms still serve as CEOs (Cai, Luo, \& Wan, 2012). On the other hand, the grant of equity incentives including stock options and restricted stocks becomes permissible in 2006 for both SOEs and non-SOEs (Conyon \& He, 2012). As a result, an increasing number of Chinese listed firms started to offer their executives equity incentives in an attempt to better align these managers' personal wealth with those of shareholders.

The extant literature has demonstrated that managerial equity ownership is an important mechanism to mitigate the horizon problem. An early study by Dechow and Sloan (1991) shows that the linkage between CEO wealth and firm value established through CEO equity ownership serves as an alternative mechanism to align managerial interests with those of shareholders as career concerns diminish. Gibbons and Murphy (1992) draw the same conclusion that stock-based incentives help better link managerial wealth with long-term, instead of short-term, firm outcomes. Recent studies in the management field likewise indicate that CEO equity incentives are effective in mitigating executives' temporal myopia to encourage a long-term orientation (Martin et al., 2016; Matta \& Beamish, 2008). By the same token, we expect that CEO equity ownership links CEOs' personal interests with their firms' long-term outcomes and thus reduces CEOs' tendency to abuse managerial slack before turnover and consequently alleviates the horizon problem. This leads to the following hypothesis:

Hypothesis 3: The increase of managerial slack in the CEO's final years in office will be smaller in firms with CEO equity owerership compared to those without.

Apart from equity ownership, the board of directors plays an essential role in protecting and promoting shareholder interests. Specifically, a board of directors has fiduciary duties to safeguard shareholder interests and to control managerial opportunism by engaging in key organization decisions such as hiring, evaluating, compensating, and firing top management (Hermalin \& Weisbach, 1988). Board capability to effectively monitor and discipline top management is affected by board composition (Finkelstein, Hambrick, \& Cannella, 2009). In particular, a board independent from CEO influences tends to possess higher monitoring quality. There is evidence that an independent board is more likely to discipline CEOs for poor firm performance and link CEO compensation to firm performance in both the western context (e.g., Boyd, 1994; Dalton, Daily, Ellstrand, \& Johnson, 1998; Krause \& Semadeni, 2014; Weisbach, 1988) and the Chinese context (e.g., Conyon \& He, 2011, 2012; Firth et al., 2006; Shen \& Lin, 2009). Pertinent to managerial slack, Chen, Lu, and Sougiannis (2012) show that US firms 
with better corporate governance quality, including those with more independent boards, are associated with a smaller degree of managerial diversion measured by asymmetric SG\&A costs. Importantly, board independence also helps alleviate the CEO horizon problem. Conyon and Florou (2006), for example, find that firms with more independent boards are associated with larger capital expenditures in years leading to $\mathrm{CEO}$ retirement compared to firms with less independent boards.

The independent director system was introduced to Chinese listed firms in 2001 with the enactment of Guidelines of Establishing the Independent Director System in Listed Companies by the China Securities Regulatory Commission (CSRG). According to this guideline, all Chinese listed firms have to ensure that their boards comprise at least one-third of independent directors by June 30, 2003. This requirement was then restated in the Code of Corporate Governance issued by CSRC in 2002. Chinese listed firms have subsequently introduced more independent directors to their boards to comply with such requirements (Conyon \& He, 2011). Firth, Wong, and Xin (2016) show that the director labor market is effective in China and independent directors do play their monitoring roles. Specifically, they document that independent directors are more likely to leave high-risk fraud-prone firms to avoid regulatory sanctions and to preserve their social status and reputation in the director labor market. We therefore predict that firms with more independent boards are more likely to carry out vigilant monitoring to constrain CEO opportunism, which we argue will lessen the increase of managerial slack induced by the horizon problem. Consequently, we predict that:

Hypothesis 4: The increase of managerial slack in the CEO's final years in office will be smaller in firms with an independent board compared to those without.

\section{DATA AND METHODS}

\section{Data and Sample Selection}

Data on managerial slack, board and ownership structure, CEO turnover, CEO compensation, as well as financial and market information, are obtained from the China Stock Market and Accounting Research database (CSMAR) provided by GuoTaiAn Information Service (GTA). The CSMAR data cover all firms listed in Chinese Shanghai and Shenzhen stock exchanges and have been widely used in previous Chinese corporate governance studies.

We first identify CEO turnover between 2003 and 2011, which is the event whenever the general manager or the chairperson of the board leaves the position and the firm. ${ }^{[1]}$ Within firms experiencing CEO turnovers, we pinpoint the last fiscal year the CEO maintains control of a firm following Huson et al. (2012). Specifically, if a CEO exit (i.e., transition out of the firm) happens before June 30 of the year, we code the year before exit as the final year ' $t$ '. If the exit happens after June 30 of the year, we code the exit year as ' $t$ '. We next code years before the exit 
year as ' $t-1$ ', ' $t-2$ ', and ' $t-3$ ', respectively. We require each firm to have four years' data, including two years immediately prior to turnover ( $t, t-1)$ and two non-final years ( $\mathrm{t}-2$, $\mathrm{t}-3)$. We then label the CEO's final years using a dummy variable 'Final Years', which is set to one for year t and year t-1 and zero for years t-2 and t-3. Our full sample, for which we have complete information on all firm level independent and control variables, consists of 1,278 firms experiencing CEO turnovers with a total of 5,758 firm year observations.

\section{Measures of Managerial Slack}

We measure managerial slack using residuals from a regression model that determines the expected (or normal) level of general administrative (G\&A) expenses. Under the Chinese Accounting Standards, G\&A is reported in a firm's income statement, which includes all expenses related to headquarter activities except for selling expenses and financial expenses. We first follow Luo et al. (2011)'s measurement of managerial perks to exclude less discretional items including bad debt expenses, unrealized holding gain or loss for inventory, the amortization of intangible assets, and compensation of administrative staff including those of top executives, from this aggregate G\&A measure. The remaining items capture expenses related to office supplies, traveling, vehicle usage, communication, insurance, benefit allowance, training, board-related activities, as well as other incidental spending such as consulting fees and litigation fees. All these expenditures are controlled by CEOs and could be deployed at their discretion. The logarithm of the remaining G\&A expenditure is denoted as ' $\mathrm{Log}(\mathrm{G} \& \mathrm{~A})$ ' to apply in our baseline model.

The next step is to calculate managerial slack as the deviation from the normal level of G\&A expenditure. We expect that the optimal level of slack (or G\&A expenditure) is influenced by firm characteristics such as firm size, the scale of tangible assets, employment intensity, asset intensity, R\&D intensity, advertising intensity, firm performance, firm growth potential, cross-listing status, as well as regional, industry, and macroeconomic factors (Anderson, Banker, Huang, \& Janakiraman, 2007; Banker, Huang, \& Natarajan, 2011). Subsequently, we define our baseline model as follows:

$$
\begin{aligned}
& \log (G \& A)_{i, t}=\alpha+\beta_{1} \log (\text { Sales })_{i, t}+\beta_{2} P P E_{i, t} / \text { Asset }_{i, t}+\beta_{3} \text { Emp_Intensity }_{i, t} \\
& \quad+\beta_{4} \text { Asset_Intensity }{ }_{i, t}+\beta_{5} \text { R\&D_Intensity }{ }_{i, t}+\beta_{6} A d v \_ \text {Intensity }{ }_{i, t} \\
& \quad+\beta_{7} \text { Sales_Growth }_{i, t}+\beta_{8} \text { Sales_Decrease }_{i, t}+\beta_{9} \text { Return }_{i, t} \\
& \quad+\beta_{10} \text { Cross }- \text { listing }_{i, t}+\beta_{11} \text { Developed }_{i, t}+\Sigma \text { Industry }+\Sigma \text { rear }+\varepsilon
\end{aligned}
$$

Here the subscripts ' $\mathrm{i}$ ' and ' $\mathrm{t}$ ' indicate firm and year, respectively. $L o g$ (Sales) is firm size measured as the logarithm of total sales. PPE/Asset indicates tangible asset intensity calculated as property, plant, and equipment costs divided by total assets. Emp_Intensity measures employment intensity calculated by dividing the number 
of employees to total sales. Asset_Intensity is calculated as the assets to sales ratio. $R E D$ Intensity is calculated as the annual $\mathrm{R} \& \mathrm{D}$ expenditure divided by total sales. Similarly, Adv_Intensity is calculated as annual advertising expenditure divided by total sales. Sales_Growth is the annual sales growth ratio, and Sales_Decrease is a dummy variable indicating whether the firm experiences a sales decline. Return is the annualized stock returns indicating the firm's market performance. Cross_listing is a dummy variable that is equal to one if the firm is cross-listed on the Hong Kong stock exchange or other overseas stock exchanges and zero otherwise, which is used to control for the influence of different regulatory regimes (Ferris, Kim, \& Noronha, 2009). Developed is a dummy variable that measures whether the firm's headquarters is located in a developed region or not. ${ }^{[2]}$ This measure captures regional difference in regulatory environment and market infrastructure in China. We also control for the industry influence by including a series of industry dummy variables constructed using CSIC industry classification codes. Finally, we include a set of year dummy variable to control for changes in regulatory environment and macroeconomic conditions that may also affect the optimal slack level. To make the best prediction about the expected reasonable level of slack, we estimate $\beta$ coefficients in Equation 1 by utilizing financial information of all listed firms between 2001 and 2011 instead of restricting to our turnover sample. Our estimation results are reported in Appendix I.

Residuals obtained from this regression are abnormal G\&A expenditure calculated as differences between actual G\&A expense and predicted G\&A expense, which are used to construct our main measure of 'Managerial Slack'. Such a residual method has the following key advantages over other methods applied in previous literature. First, G\&A or SG\&A expenditure scaled by assets or sales has been utilized in prior literature to measure absorbed slack, i.e., resources that have been absorbed by the organization but may be redeployed and recovered through increased efficiencies (e.g., Ju \& Zhao, 2009; Singh, 1986). However, a size scaled G\&A expenditure is insufficient to isolate organizational inefficiency and managerial diversion from legitimate performance-enhancing functions of G\&A expenditure, since many other factors that we identified above also affect the optimal level of G\&A expenditure. Second, total G\&A expenditure is applied to measure the magnitude of executive perks in China, a construct similar to our definition of managerial slack (Adithipyangkul, Alon, \& Zhang, 2011). This aggregate method is still unable to distinguish between the legitimate and illegitimate components of perks embedded in total G\&A expenditure. Third, some studies use voluntarily disclosed itemized expenditure to measure executive

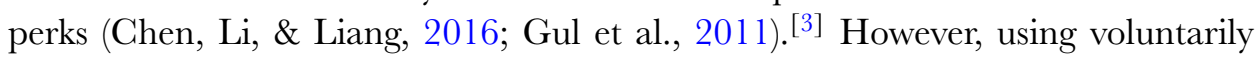
disclosed data significantly reduces the available sample size. For example, Chen et al. (2016) estimate that less than 50\% of listed Chinese firms in their sample chose to disclose perk-related expenses. In addition, these disclosed items still mix normal business expenditure with managerial slack. For example, business travel expenses might be completely legitimate and wisely used by managers to build 
relationships with suppliers and buyers, while it might also be abused by managers to enjoy private benefits. Finally, the sample quality may be contaminated due to self-selection bias. That is, only firms without excessive consumption of managerial slack would choose to disclose these items in detail, while firms with suspicious expenditure may refrain from reporting these details but opt to hide them in the aggregate G\&A term. We therefore contend that our measure of managerial slack is better than methods used in previous studies to capture the underlying construct.

Within our sample period we note that the average total G\&A expense is roughly 77.05 million RMB. After deducting predicted normal business expenses of 73.29 million RMB, average abnormal executive expenses, i.e., managerial slack, are as high as 3.75 million RMB, about seven times of average executive pay (0.5 million). This estimate is consistent with Chen et al. (2016)'s estimate of discretional managerial expenditure in China, which they defined as managerial perks. Using voluntarily disclosed expenditure data, they report that total managerial perks are roughly eight times of average executive compensation in their sample of Chinese listed firms.

Since the residual method we propose here might be sensitive to the choice of the underlying baseline model, we also use three alternative methods to capture the construct of managerial slack. First, we follow Luo et al. (2011) to create an asset scaled measure of G\&A expense by substituting the 'Log (G\&A)' measure in Equation 1 with 'G\&A/Asset' in our baseline model and then use residuals from this new model to capture managerial slack. It is denoted as 'Slack-Scaled by Asset'. Next, we follow the procedure proposed in Chen et al. (2012) to capture abnormal selling, general, and administrative costs (SG\&A) by replacing ' $\log (\mathrm{G} \& \mathrm{~A})$ ' with $\log$ value of total SG\&A costs excluding certain non-discretionary items. Residuals from this model are labeled as 'Slack-SG\&A'. Finally, we obtain a narrower measure of G\&A expense using 'other cash flows related to operating activities' reported in the cash flow statement. This item typically includes management expenses related to business travel such as entertainment and vehicle usage (Cai et al., 2011). We use the logarithm of this cash expense as the dependent variable in Equation 1 and obtain residuals on abnormal cash flow labeled as 'Slack-Cash Expense'. Similar to our main measure of managerial slack, we use financial information for all listed firms between 2001 and 2011 to construct baseline models in these alternative measures. We argue that the combination of these different measures provides a more solid approach to fully appreciate whether there is excess managerial slack in CEO final years in office.

\section{Independent and Control Variables}

As we noted above, we use variable 'Final Years' to capture CEOs' final years in office. It is equal to 1 if the year is one of the last two years prior to CEO turnover 
(year $t$, year $\mathrm{t}-1$ ), and 0 if it is year $\mathrm{t}-2$ or year $\mathrm{t}-3$. Because a forced $\mathrm{CEO}$ turnover lack of an advance notice may reduce the opportunity for the $\mathrm{CEO}$ to shirk or to consume on-the-job private benefits, we also use a fine-grained turnover measure that excludes all forced turnover events to define CEO final years in office as a robustness check. [4] ' $S O E$ ' is a dummy variable indicating whether the firm is a state-owned enterprise. 'CEO Share' is a dummy variable measuring the presence of CEO equity ownership. 'Indep. Board' is a dummy variable capturing whether the board has more than one third of outside directors. We next create three sets of interaction variables by interacting SOE, CEO Share, and Independent Board with Final Years respectively to estimate moderating roles of these corporate governance variables.

Our model also consists of other control variables that may influence the magnitude of managerial slack and horizon problem (e.g., Finkelstein et al., 2009; Shen \& Lin, 2009). First, Adithpyangkul et al. (2011) and Chen et al. (2016) suggest that managerial perks (or slack in our term) may substitute for insufficient cash compensation offered to Chinese managers. We thus explicitly include 'Executive Pay' as a control variable, which is measured as the logarithm value of the average compensation of the top three highest paid executives. ${ }^{[5]}$ We next control for other board and ownership characteristics. We measure 'Board Size' as the number of directors on the board. We create an indicator variable 'Combine' to measure whether the post of the $\mathrm{CEO}$ and the chairperson is combined. 'Largest $\mathrm{SH}^{\circ}$ ' represents the percentage ownership of the controlling shareholder. To control for the quality of external governance mechanism, we use a dummy variable 'Auditor' to indicate whether the firm hires a major auditor, i.e., one of the largest ten auditors in China ranked by assets (DeFond, Wong, \& Li, 2000). We also control for the following firm characteristics. 'Log Assets' is a measure of company size and complexity calculated as the logarithm value of total assets. Firm performance is measured using the return on assets ratio, denoted as 'Return on assets'. We control for the influence of declining performance using a dummy variable denoted as 'Performance decline', which is equal to one if the current year ROA is smaller than the previous year's and zero otherwise. We measure 'Sales growth' using annual sales growth ratio, 'Leverage' using long-term liability divided by total assets, and 'Free cash flow' using net operating cash flow divided by total assets.

\section{Statistical Methods}

We estimate a standard panel data model containing firm-level fixed effects to test our hypotheses. The fixed-effects model is inherently a change model that investigates how changes in CEO final-year status may affect changes in managerial slack for a given firm. By testing within-sample instead of betweensample variations, the fixed-effect method enables us to mitigate endogeneity problems created by unobserved firm specific variables that might affect the linkage 
between CEO final years and managerial slack. Our model is specified below:

$$
\begin{aligned}
& \text { ManagerialSlack }_{i, t}=\alpha_{i}+\beta_{1}{\text { FinalY } \text { ears }_{i, t}+\beta_{2} \text { SOE }_{i, t}+\beta_{3} \text { CEOShare }_{i, t}}+\beta_{4} \text { IndepBoard }_{i, t}+\gamma_{1} \text { ExecPay }_{i, t}+\gamma_{2} \text { BoardSize }_{i, t}+\gamma_{3} \text { Combine }_{i, t} \\
& \quad+\gamma_{4} \text { LargestSH }_{i, t}+\gamma_{5} \text { Auditor }_{i, t}+\gamma_{6} \text { LogAssets }_{i, t}++\gamma_{7} \text { ROA }_{i, t} \\
& \quad+\gamma_{8} \text { PerfDecline }_{i, t}+\gamma_{9} \text { SalesGrowth }_{i, t}+\gamma_{10} \text { Leverage }_{i, t} \\
& \quad+\gamma_{11} \text { FreeCashFlow }_{i, t}+\lambda_{t}+\varepsilon_{i t}
\end{aligned}
$$

Here 'Managerial Slackit' is the abnormal G\&A expenses for firm ' $i$ ' at time ' $t$ ' calculated using residuals from Equation 1. The term 'Final Years' is an indicator variable coded as 1 if the CEO is in the final two years of office and zero otherwise. The coefficient $\beta_{1}$ is expected to be positive, implying that managerial slack increases in the CEO's final years in office. The model also contains a set of firm level control variables as specified above. The term $\alpha_{\mathrm{i}}$ is a set of firm fixed effects controlling for unobserved non-time varying firm-specific factors that might influence managerial slack (Wooldridge, 2010). $\lambda_{t}$ is a set of time dummy variables and $\varepsilon_{\mathrm{it}}$ is the error term.

\section{RESULTS}

\section{Descriptive Statistics}

Table 1 provides some basic descriptive statistics along with a correlation matrix for main variables used in our analysis. We find that an average firm has 9 board members and $83 \%$ of firms have at least one-third of independent directors on their boards. Approximately $11 \%$ of firms have a combined leadership position. An average CEO holds no shares in his/her firm. The largest shareholder on average owns $39 \%$ of the firm. The percentage of SOEs in our sample is $71 \%$. We also find that $29 \%$ of sample firms hire a top-ten auditor. The average return on assets ratio is approximately 0.03 , average sales growth rate is 0.16 , and the average leverage ratio is 0.06 . These patterns are broadly consistent with other corporate governance studies using Chinese data (e.g., Conyon \& He, 2011, 2012; Firth et al., 2006, 2007; He \& Fang, 2016; Shen \& Lin, 2009). Importantly, we find that managerial slack is significantly higher during CEO final years in office. The unconditional data are thus consistent with our prediction in $\mathrm{H} 1$.

Table 2a contrasts managerial slack in CEO final years with those in non-final years using all four slack measures specified above. We also report average executive compensation for comparison. Both mean and median values are reported along with t-statistics for equal means and $\mathrm{z}$ scores for the Wilcoxon rank sum test for equal medians. Table 2a indicates that managerial slack is significantly higher in CEO final years compared to non-final years across all four measures of managerial slack in terms of both mean and median values, with $\mathrm{p}$ value ranging from 0.00 to 0.02 . This result is consistent with our prediction that the horizon problem prompts an increase in managerial slack right before CEO turnover compared 
Table 1. Descriptive statistics and correlation matrix

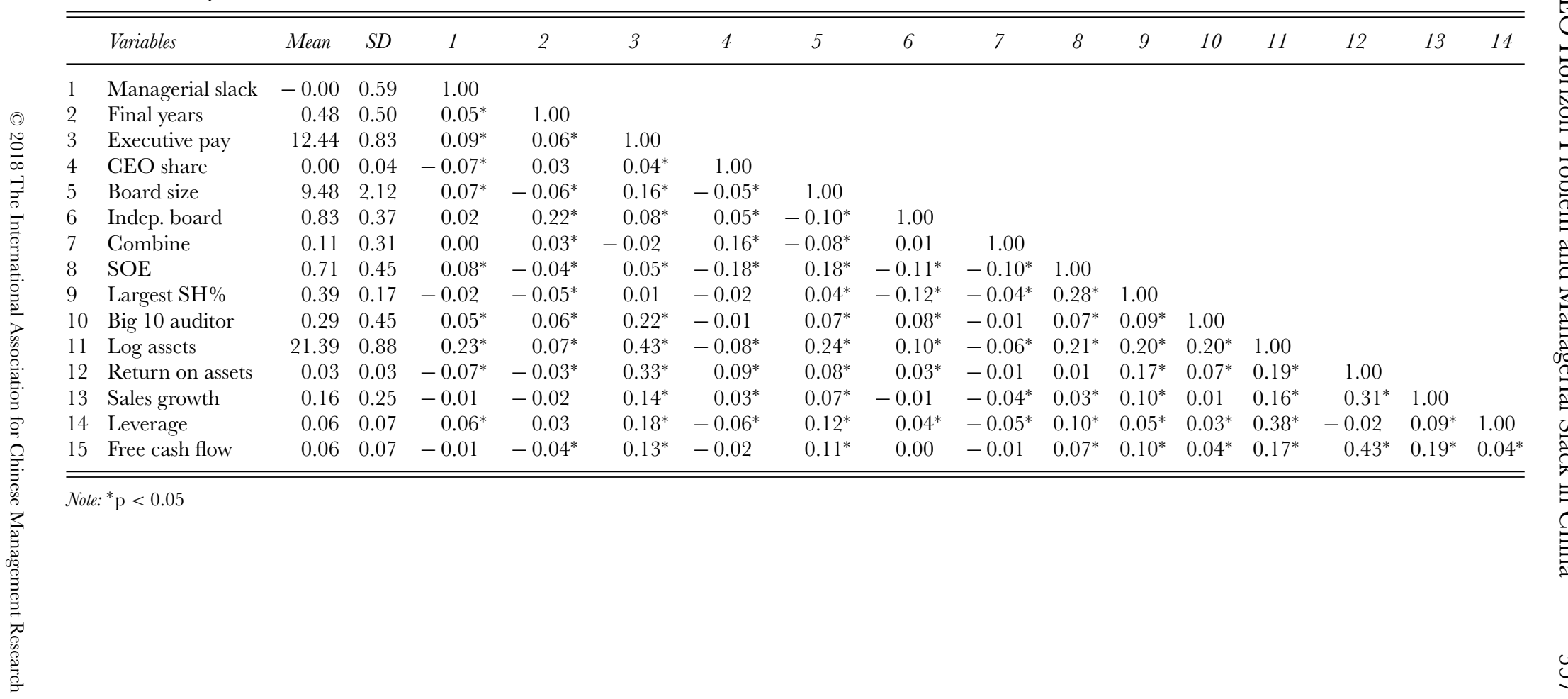


Table 2a. Managerial slack in final years vs. non-final years

\begin{tabular}{|c|c|c|c|c|c|c|}
\hline Variables & & $\begin{array}{l}\text { Non-final } \\
\text { Years }\end{array}$ & Final Years & $\begin{array}{c}\Delta \text { Managerial } \\
\text { Slack }\end{array}$ & $\begin{array}{l}\text { t stat.l } \\
z \text { score }\end{array}$ & P Value \\
\hline \multirow[t]{2}{*}{ Managerial Slack } & Mean & -0.03 & 0.02 & 0.05 & 3.50 & $0.00^{* * *}$ \\
\hline & Median & -0.04 & 0.02 & 0.06 & 3.65 & $0.00^{* * *}$ \\
\hline \multicolumn{7}{|l|}{ Alternative Measures } \\
\hline \multirow[t]{2}{*}{ Slack-Asset Scaled } & Mean & -0.12 & 0.06 & 0.18 & 2.99 & $0.00^{* * *}$ \\
\hline & Median & -0.68 & -0.45 & 0.23 & 2.89 & $0.00^{* * *}$ \\
\hline \multirow{2}{*}{ Slack-SG\&A } & Mean & -0.01 & 0.02 & 0.03 & 2.31 & $0.02^{* *}$ \\
\hline & Median & -0.02 & 0.02 & 0.04 & 2.51 & $0.01^{* *}$ \\
\hline \multirow[t]{2}{*}{ Slack-Cash Expense } & Mean & -0.04 & 0.00 & 0.04 & 2.34 & $0.02^{* *}$ \\
\hline & Median & -0.04 & 0.02 & 0.06 & 2.27 & $0.02^{* *}$ \\
\hline \multirow[t]{2}{*}{ Executive Comp. } & Mean & 12.38 & 12.48 & 0.10 & 3.63 & $0.00^{* * *}$ \\
\hline & Median & 12.41 & 12.52 & 0.11 & 4.09 & $0.00^{* * *}$ \\
\hline
\end{tabular}

Notes: Both mean and median values are reported. $\mathrm{t}$ statistics from two tailed $\mathrm{t}$-test for equal mean and $\mathrm{Z}$ values for Wilcoxon rank sum test for equal median are presented with respective significance level. * $\mathrm{p}<$ $0.10 ;{ }^{* *} \mathrm{p}<0.05 ;{ }^{* * *} \mathrm{p}<0.01$.

to earlier years. Importantly, we notice that average executive compensation is also significantly higher in the CEO's final years in office. Therefore, there is no evidence that increased managerial slack before CEO turnover is used to offset insufficient cash compensation in this period.

To illustrate the role of corporate governance mechanisms in constraining the influence of the horizon problem on managerial slack, we split our samples based on three sets of corporate governance variables: SOEs vs. non-SOEs, firms with CEO equity ownership vs. those without, and firms with independent boards vs. those without. For each set of firms, we calculate mean values of their managerial slack during and before CEO final years in office. We present differences in managerial slack between these two periods as well as t-statistics for equal mean tests for each set of subsamples in Table $2 \mathrm{~b}$. We also report $\mathrm{F}$ values from two-factor ANOVA tests on our difference-in-difference results to test whether changes in managerial slack are significantly different within each set of governance variables. Table $2 \mathrm{~b}$ suggests that SOEs experience a significant increase in managerial slack during CEO final years, with the slack level rising from 0.00 to $0.06(\mathrm{p}=0.00)$. In contrast, no statistically significant increase in slack is identified for non-SOEs $(\mathrm{p}=0.32)$. In addition, our difference-indifference test suggests that the positive increase in managerial slack right before CEO turnover is significantly larger for SOEs than for non-SOEs ( $F=27.77, p$ $=0.00$ ), which confirms our prediction of $\mathrm{H} 2$ that the horizon problem is severer in SOEs than in non-SOEs. We also find that firms whose CEOs have no equity stakes experience significant increase of managerial slack during their final years in office $(p=0.00)$, while a statistically significant difference is not identified for the subgroup of firms with CEO equity ownership. The difference in the change of managerial slack between these two groups is statistically significant $(\mathrm{F}=7.00$, 
Table 2b. Managerial slack in final years vs. non-final years for different corporate governance mechanisms

\begin{tabular}{|c|c|c|c|c|c|c|c|}
\hline \multirow[b]{2}{*}{$\begin{array}{l}\text { Governance } \\
\text { Structure }\end{array}$} & & \multicolumn{2}{|c|}{ Mean (se.) } & \multirow[b]{2}{*}{$\begin{array}{c}\Delta \text { Mean } / \\
\text { t stat. }\end{array}$} & \multirow[b]{2}{*}{$P$ value } & \multirow[b]{2}{*}{$\begin{array}{l}\text { Diff.in } \\
\text { Diff. }\end{array}$} & \multirow[b]{2}{*}{$\begin{array}{l}F \text { stat. } \\
\text { P value }\end{array}$} \\
\hline & & $\begin{array}{l}\text { Non-final } \\
\text { Years }\end{array}$ & $\begin{array}{l}\text { Final } \\
\text { Years }\end{array}$ & & & & \\
\hline \multirow[t]{2}{*}{$\begin{array}{l}\text { Ownership } \\
\text { Type }\end{array}$} & SOE & $\begin{array}{c}0.00 \\
(0.56)\end{array}$ & $\begin{array}{c}0.06 \\
(0.57)\end{array}$ & $\begin{array}{c}0.06 \\
\mathrm{t}=3.25\end{array}$ & $0.00^{* * *}$ & & $\mathrm{~F}=27.77$ \\
\hline & Non-SOE & $\begin{array}{r}-0.11 \\
(0.66)\end{array}$ & $\begin{array}{r}-0.07 \\
(0.59)\end{array}$ & $\begin{array}{c}0.04 \\
\mathrm{t}=0.99\end{array}$ & 0.32 & 0.02 & $0.00^{* * *}$ \\
\hline \multirow{4}{*}{$\begin{array}{l}\text { CEO Equity } \\
\text { Ownership }\end{array}$} & Without & -0.04 & 0.02 & 0.06 & $0.00^{* * *}$ & & $\mathrm{~F}=7.00$ \\
\hline & Equity & $(0.60)$ & $(0.61)$ & $\mathrm{t}=3.43$ & & & \\
\hline & With & -0.00 & 0.03 & 0.03 & 0.23 & 0.03 & $0.00^{* * *}$ \\
\hline & Equity & $(0.56)$ & $(0.53)$ & $\mathrm{t}=1.19$ & & & \\
\hline \multirow{3}{*}{$\begin{array}{l}\text { Board } \\
\text { Independence }\end{array}$} & Non-indep. & -0.08 & 0.13 & 0.21 & $0.00^{* * *}$ & & $\mathrm{~F}=6.50$ \\
\hline & & $(0.59)$ & $(0.76)$ & $\mathrm{t}=4.43$ & & & \\
\hline & $\begin{array}{l}\text { Indep. } \\
\text { Board }\end{array}$ & $\begin{array}{r}-0.01 \\
(0.59)\end{array}$ & $\begin{array}{c}0.02 \\
(0.58)\end{array}$ & $\begin{array}{c}0.03 \\
t=1.69\end{array}$ & $0.09^{*}$ & 0.18 & $0.00^{* * *}$ \\
\hline
\end{tabular}

Notes: Mean values are reported with standard errors in parenthesis. $t$ statistics from two tailed t-test for equal mean and F statistics from ANOVA test are present. ${ }^{*} \mathrm{p}<0.10 ;{ }^{* *} \mathrm{p}<0.05 ;{ }^{* * *} \mathrm{p}<0.01$

$\mathrm{p}=0.00$ ), thus supports $\mathrm{H} 3$ that $\mathrm{CEO}$ equity ownership lessens the impact of the horizon problem on managerial slack. Finally, Table $2 b$ suggests that firms without independent boards undergo a significant surge of managerial slack right before CEO turnover, with slack increasing from -0.08 to $0.13(\mathrm{p}=0.00)$, while such an increase is only marginally significant for firms with independent boards $(p=0.09)$. The difference-in-difference test between these two subgroups is also statistically significant $(\mathrm{F}=6.50, \mathrm{p}=0.00)$, which is consistent with the prediction of $\mathrm{H} 4$ that board independence mitigates the influence of horizon problem on managerial slack. Overall, these analyses provide preliminary and important empirical support to all four hypotheses. That is, the horizon problem results in increased managerial slack in a CEO's final years in office, and such an increase is more salient in SOEs, firms without CEO equity ownership and firms without an independent board.

\section{Multivariate Analysis}

Table 3 contains our main regression results to test $\mathrm{H} 1$, with column 1 reporting standard ordinary least squares (OLS) estimates and column 2 reporting firmlevel fixed effects estimates, both based on the full turnover sample. Column 3 presents results from the confined voluntary turnover sample using the fixedeffect model. The VIF test for multi-collinearity indicates that the mean VIF for all variables is 2.49 when time dummy variables are included, and 1.22 when time dummy variables are excluded. VIF values range from 1.04 to 1.61 for all 
Table 3. Managerial slack in CEOs' final years in office

\begin{tabular}{|c|c|c|c|c|c|c|}
\hline & \multicolumn{2}{|c|}{$\begin{array}{c}\text { Managerial Slack } \\
\text { Full Turnover Sample } \\
\text { OLS }\end{array}$} & \multicolumn{2}{|c|}{$\begin{array}{c}\text { Managerial Slack } \\
\text { Full Turnover Sample } \\
\text { Fixed Effects }\end{array}$} & \multicolumn{2}{|c|}{$\begin{array}{l}\text { Managerial Slack } \\
\text { Voluntary Turnover } \\
\text { Fixed Effects }\end{array}$} \\
\hline & (1) & $p$ value & (2) & $p$ value & (3) & $p$ value \\
\hline Final years [H1] & $\begin{array}{c}0.04 \\
(0.01)\end{array}$ & $0.00^{* * *}$ & $\begin{array}{c}0.04 \\
(0.01)\end{array}$ & $0.00^{* * *}$ & $\begin{array}{c}0.03 \\
(0.01)\end{array}$ & $0.01^{* *}$ \\
\hline Executive pay & $\begin{array}{c}0.04 \\
(0.02)\end{array}$ & $0.05^{* *}$ & $\begin{array}{r}-0.00 \\
(0.02)\end{array}$ & 0.83 & $\begin{array}{c}0.00 \\
(0.02)\end{array}$ & 0.98 \\
\hline SOE & $\begin{array}{c}0.06 \\
(0.03)\end{array}$ & $0.06^{*}$ & $\begin{array}{c}0.03 \\
(0.03)\end{array}$ & 0.30 & $\begin{array}{c}0.03 \\
(0.03)\end{array}$ & 0.29 \\
\hline CEO share & $\begin{array}{r}-0.41^{*} \\
(0.22)\end{array}$ & $0.06^{*}$ & $\begin{array}{r}-0.09 \\
(0.25)\end{array}$ & 0.74 & $\begin{array}{r}-0.22 \\
(0.29)\end{array}$ & 0.46 \\
\hline Indep. board & $\begin{array}{r}-0.02 \\
(0.04)\end{array}$ & 0.69 & $\begin{array}{r}-0.03 \\
(0.02)\end{array}$ & 0.15 & $\begin{array}{r}-0.02 \\
(0.02)\end{array}$ & 0.32 \\
\hline Board size & $\begin{array}{r}-0.00 \\
(0.01)\end{array}$ & 0.69 & $\begin{array}{c}0.01 \\
(0.00)\end{array}$ & 0.29 & $\begin{array}{c}0.00 \\
(0.01)\end{array}$ & 0.52 \\
\hline Combine & $\begin{array}{c}0.04 \\
(0.04)\end{array}$ & 0.26 & $\begin{array}{r}-0.00 \\
(0.02)\end{array}$ & 0.92 & $\begin{array}{c}0.00 \\
(0.02)\end{array}$ & 0.88 \\
\hline Largest SH \% & $\begin{array}{r}-0.26 \\
(0.09)\end{array}$ & $0.00^{* * *}$ & $\begin{array}{c}0.08 \\
(0.08)\end{array}$ & 0.32 & $\begin{array}{c}0.12 \\
(0.09)\end{array}$ & 0.16 \\
\hline Big 10 auditor & $\begin{array}{c}0.01 \\
(0.03)\end{array}$ & 0.75 & $\begin{array}{r}-0.01 \\
(0.02)\end{array}$ & 0.71 & $\begin{array}{c}0.01 \\
(0.02)\end{array}$ & 0.68 \\
\hline Log assets & $\begin{array}{c}0.18 \\
(0.02)\end{array}$ & $0.00^{* * *}$ & $\begin{array}{c}0.19 \\
(0.02)\end{array}$ & $0.00^{* * *}$ & $\begin{array}{c}0.19 \\
(0.02)\end{array}$ & $0.00^{* * *}$ \\
\hline Return on assets & $\begin{array}{r}-2.05 \\
(0.41)\end{array}$ & $0.00^{* * *}$ & $\begin{array}{r}-3.42 \\
(0.27)\end{array}$ & $0.00^{* * *}$ & $\begin{array}{r}-3.20 \\
(0.29)\end{array}$ & $0.00^{* * *}$ \\
\hline Performance decline & $\begin{array}{r}-0.10 \\
(0.02)\end{array}$ & $0.00^{* * *}$ & $\begin{array}{r}-0.04 \\
(0.01)\end{array}$ & $0.00^{* * *}$ & $\begin{array}{r}-0.04 \\
(0.01)\end{array}$ & $0.00^{* * *}$ \\
\hline Sales growth & $\begin{array}{r}-0.03 \\
(0.04)\end{array}$ & 0.41 & $\begin{array}{c}0.08 \\
(0.02)\end{array}$ & $0.00^{* * *}$ & $\begin{array}{c}0.08 \\
(0.03)\end{array}$ & $0.00^{* * *}$ \\
\hline Leverage & $\begin{array}{r}-0.33 \\
(0.19)\end{array}$ & $0.08^{*}$ & $\begin{array}{c}0.12 \\
(0.12)\end{array}$ & 0.33 & $\begin{array}{c}0.08 \\
(0.13)\end{array}$ & 0.53 \\
\hline Free cash flow & $\begin{array}{r}-0.13 \\
(0.16)\end{array}$ & 0.44 & $\begin{array}{r}-0.08 \\
(0.10)\end{array}$ & 0.40 & $\begin{array}{r}-0.12 \\
(0.11)\end{array}$ & 0.26 \\
\hline Year effects & Yes & & Yes & & Yes & \\
\hline Industry effects & Yes & & No & & No & \\
\hline Constant & $\begin{array}{r}-4.20 \\
(0.36) \\
\end{array}$ & $0.00^{* * *}$ & $\begin{array}{r}-4.12 \\
(0.41) \\
\end{array}$ & $0.00^{* * *}$ & $\begin{array}{r}-4.15 \\
(0.44) \\
\end{array}$ & $0.00^{* * *}$ \\
\hline Observations & 5,758 & & 5,758 & & 5,116 & \\
\hline \# of Firms & 1,278 & & 1,278 & & 1,211 & \\
\hline $\operatorname{Adj} . R^{2}$ & 0.11 & & 0.11 & & 0.11 & \\
\hline
\end{tabular}

Notes: Coefficients are reported with robust standard errors in parenthesis. $\mathrm{p}$ value is calculated based on two-tailed t statistics. ${ }^{*} \mathrm{p}<0.10 ;{ }^{* *} \mathrm{p}<0.05$; $^{* * *} \mathrm{p}<0.01$.

non-time dummy variables. Therefore, there is no severe multi-collinearity problem in our multivariate analyses.

Table 3 indicates a statistically significant positive correlation between managerial slack and CEO final years, with $\mathrm{p}$ values in all models smaller than 0.01. This relationship is economically significant. Specifically, Table 3 suggests 
that managerial slack is approximately 3\% (Column 3) to 4\% (Columns 1 \& 2) higher during the CEO's final two years in office compared to earlier years. This translates into about 2.3 million to 3.1 million RMB excessive expenditure calculated using the mean level of G\&A expenses. The multivariate regression results therefore provide strong support to our $\mathrm{H} 1$ that the horizon problem leads to increased managerial slack during the CEO's final years in office.

Table 4 tests hypotheses 2 through 4 using the split-sample method to evaluate the moderating role of firm governance structures. We split the sample based on ownership structure (SOEs vs. non-SOEs) in columns 1 and 2 to test $\mathrm{H} 2$, on CEO equity ownership in columns 3 and 4 to investigate $\mathrm{H} 3$, and on board structure in columns 5 and 6 to test H4. We apply the firm-level fixed-effects panel data method in all models. Our goal is to see whether the association between managerial slack and CEO final years is significantly different within each pair of subsample splits.

Table 4 indicates that the coefficient of 'Final Years' is $0.04(\mathrm{p}=0.00)$ in the SOE subsample, which suggests that managerial slack will rise $4 \%$ in CEO final years in SOEs. In contrast, we observe no significant increase in slack in the non-SOE subsample. These results are consistent with the prediction of $\mathrm{H} 2$ that private ownership reduces the horizon problem. In addition, we find a positive and significant coefficient of $0.04(\mathrm{p}=0.00)$ in the subsample of firms without CEO equity ownership, while we do not isolate a statistically significant coefficient in firms with CEO equity ownership. H3 is thus confirmed that the increase in managerial slack during CEOs' final years is more salient in the absence of managerial equity ownership. Table 4 also suggests that firms with less independent boards are associated with significantly higher managerial slack in CEOs' final years $(\beta=0.15, \mathrm{p}=0.00)$, which suggests that managerial slack in these firms will increase 15\% right before CEO turnover. In sharp contrast, firms with more independent boards are associated with only a modest $2 \%$ increase in slack during the CEO's final years $(\mathrm{p}=0.06)$. These results support $\mathrm{H} 4$ that board independence mitigates the CEO horizon effect. Overall, evidence present in Table 4 suggests that better quality corporate governance mechanisms help alleviate the impact of the horizon problem on managerial slack.

To further illustrate the moderating role of corporate governance structures, we next create interaction variables between 'Final Years' and all three corporate governance variables. Given there are very few within-sample variations in SOE status, CEO equity ownership and board independence, we apply the pooled OLS method instead of the firm-level fixed effects method to conduct our test. We report our results in Table 5. Column 1 tests the moderating role of SOE status, column 2 tests the role of CEO equity ownership, column 3 evaluates the role of board independence, and column 4 includes all three interaction variables simultaneously. First, we notice that the coefficients of 'Final Years' are significantly positive in all models, which again confirms $\mathrm{H} 1$ that managerial slack increases in CEO final years. In addition, we notice that the increase in managerial slack is even larger for SOEs as indicated by the significantly positive coefficient 
Table 4. Managerial slack and corporate governance mechanisms: Split-sample tests

\begin{tabular}{|c|c|c|c|c|c|c|c|c|c|c|c|c|}
\hline & $\begin{array}{l}\text { Non- } \\
\text { Fixed }\end{array}$ & $\begin{array}{l}O E \\
\text { fects }\end{array}$ & \multicolumn{2}{|c|}{$\begin{array}{c}S O E \\
\text { Fixed Effects }\end{array}$} & \multicolumn{2}{|c|}{$\begin{array}{c}\text { With CEO } \\
\text { Equity } \\
\text { Ownership } \\
\text { Fixed Effects }\end{array}$} & \multicolumn{2}{|c|}{$\begin{array}{l}\text { Without CEO } \\
\text { Equity } \\
\text { Ownership } \\
\text { Fixed Effects }\end{array}$} & \multicolumn{2}{|c|}{$\begin{array}{l}\text { Independent Board } \\
\text { Fixed Effects }\end{array}$} & \multicolumn{2}{|c|}{$\begin{array}{c}\text { Non-independent } \\
\text { Board } \\
\text { Fixed Effects }\end{array}$} \\
\hline & \multicolumn{4}{|c|}{$H 2$} & \multicolumn{4}{|c|}{$H 3$} & \multicolumn{4}{|c|}{$H 4$} \\
\hline & (1) & $p$ value & (2) & p value & (3) & $p$ value & (4) & $p$ value & (5) & p value & (6) & $p$ value \\
\hline Final years & $\begin{array}{c}0.01 \\
(0.03)\end{array}$ & 0.68 & $\begin{array}{c}0.04 \\
(0.01)\end{array}$ & $0.00^{* * *}$ & $\begin{array}{c}0.01 \\
(0.02)\end{array}$ & 0.74 & $\begin{array}{c}0.04 \\
(0.01)\end{array}$ & $0.00^{* * *}$ & $\begin{array}{c}0.02 \\
(0.01)\end{array}$ & $0.06^{*}$ & $\begin{array}{c}0.15 \\
(0.05)\end{array}$ & $0.00^{* * *}$ \\
\hline Executive comp. & $\begin{array}{r}-0.05 \\
(0.04)\end{array}$ & 0.18 & $\begin{array}{r}-0.01 \\
(0.02)\end{array}$ & 0.68 & $\begin{array}{r}-0.04 \\
(0.03)\end{array}$ & 0.17 & $\begin{array}{r}-0.00 \\
(0.02)\end{array}$ & 0.98 & $\begin{array}{c}0.00 \\
(0.02)\end{array}$ & 0.91 & $\begin{array}{r}-0.03 \\
(0.06)\end{array}$ & 0.59 \\
\hline SOE & $\begin{array}{l}1 \\
1\end{array}$ & & ' & & $\begin{array}{r}-0.23 \\
(0.07)\end{array}$ & $0.00^{* * *}$ & $\begin{array}{c}0.10 \\
(0.04)\end{array}$ & $0.00^{* * *}$ & $\begin{array}{c}0.08 \\
(0.03)\end{array}$ & $0.02^{* *}$ & $\begin{array}{r}-0.05 \\
(0.12)\end{array}$ & 0.71 \\
\hline CEO share & $\begin{array}{c}0.05 \\
(0.04)\end{array}$ & 0.18 & $\begin{array}{c}0.00 \\
(0.02)\end{array}$ & 0.85 & / & & / & & $\begin{array}{c}0.02 \\
(0.02)\end{array}$ & 0.22 & $\begin{array}{c}0.06 \\
(0.06)\end{array}$ & 0.34 \\
\hline Indep. board & $\begin{array}{c}0.05 \\
(0.06)\end{array}$ & 0.41 & $\begin{array}{r}-0.04 \\
(0.02)\end{array}$ & 0.12 & $\begin{array}{r}-0.01 \\
(0.04)\end{array}$ & 0.78 & $\begin{array}{r}-0.03 \\
(0.03)\end{array}$ & 0.27 & / & & $\begin{array}{l}1 \\
1\end{array}$ & \\
\hline Board size & $\begin{array}{r}-0.01 \\
(0.01)\end{array}$ & 0.34 & $\begin{array}{c}0.01 \\
(0.01)\end{array}$ & 0.15 & $\begin{array}{r}-0.00 \\
(0.01)\end{array}$ & 0.94 & $\begin{array}{c}0.00 \\
(0.01)\end{array}$ & 0.78 & $\begin{array}{r}-0.01 \\
(0.01)\end{array}$ & 0.21 & $\begin{array}{c}0.04 \\
(0.02)\end{array}$ & $0.02^{* *}$ \\
\hline Combine & $\begin{array}{r}-0.02 \\
(0.04)\end{array}$ & 0.66 & $\begin{array}{c}0.01 \\
(0.03)\end{array}$ & 0.84 & $\begin{array}{c}0.05 \\
(0.04)\end{array}$ & 0.21 & $\begin{array}{r}-0.03 \\
(0.03)\end{array}$ & 0.35 & $\begin{array}{r}-0.00 \\
(0.02)\end{array}$ & 0.91 & $\begin{array}{c}0.04 \\
(0.09)\end{array}$ & 0.63 \\
\hline Largest SH\% & $\begin{array}{c}0.21 \\
(0.18)\end{array}$ & 0.25 & $\begin{array}{r}-0.02 \\
(0.10)\end{array}$ & 0.82 & $\begin{array}{r}-0.25 \\
(0.20)\end{array}$ & 0.21 & $\begin{array}{c}0.04 \\
(0.10)\end{array}$ & 0.67 & $\begin{array}{c}0.00 \\
(0.09)\end{array}$ & 0.97 & $\begin{array}{r}-0.79 \\
(0.44)\end{array}$ & $0.08^{*}$ \\
\hline Big 10 auditor & $\begin{array}{r}-0.04 \\
(0.05)\end{array}$ & 0.41 & $\begin{array}{r}-0.01 \\
(0.02)\end{array}$ & 0.49 & $\begin{array}{r}-0.11 \\
(0.04)\end{array}$ & $0.00^{* * *}$ & $\begin{array}{c}0.03 \\
(0.02)\end{array}$ & 0.24 & $\begin{array}{r}-0.01 \\
(0.02)\end{array}$ & 0.49 & $\begin{array}{c}0.03 \\
(0.10)\end{array}$ & 0.76 \\
\hline Log total assets & $\begin{array}{c}0.07 \\
(0.04)\end{array}$ & 0.12 & $\begin{array}{c}0.25 \\
(0.02)\end{array}$ & $0.00^{* * *}$ & $\begin{array}{c}0.31 \\
(0.05)\end{array}$ & $0.00^{* * *}$ & $\begin{array}{c}0.19 \\
(0.02)\end{array}$ & $0.00^{* * *}$ & $\begin{array}{c}0.19 \\
(0.02)\end{array}$ & $0.00^{* * *}$ & $\begin{array}{r}-0.26 \\
(0.11)\end{array}$ & $0.02^{* *}$ \\
\hline
\end{tabular}


Table 4. Continued

\begin{tabular}{|c|c|c|c|c|c|c|c|c|c|c|c|c|}
\hline & \multicolumn{2}{|c|}{$\begin{array}{c}\text { Non-SOE } \\
\text { Fixed Effects }\end{array}$} & \multicolumn{2}{|c|}{$\begin{array}{c}S O E \\
\text { Fixed Effects }\end{array}$} & \multicolumn{2}{|c|}{$\begin{array}{c}\text { With CEO } \\
\text { Equity } \\
\text { Ownership } \\
\text { Fixed Effects }\end{array}$} & \multicolumn{2}{|c|}{$\begin{array}{c}\text { Without CEO } \\
\text { Equity } \\
\text { Ownership } \\
\text { Fixed Effects }\end{array}$} & \multicolumn{2}{|c|}{$\begin{array}{l}\text { Independent Board } \\
\text { Fixed Effects }\end{array}$} & \multicolumn{2}{|c|}{$\begin{array}{c}\text { Non-independent } \\
\text { Board } \\
\text { Fixed Effects }\end{array}$} \\
\hline & \multicolumn{4}{|c|}{$H 2$} & \multicolumn{4}{|c|}{$H 3$} & \multicolumn{4}{|c|}{$H 4$} \\
\hline & (1) & pvalue & (2) & p value & (3) & $p$ value & (4) & p value & (5) & $p$ value & (6) & $p$ value \\
\hline Return on assets & $\begin{array}{r}-4.50 \\
(0.53)\end{array}$ & $0.00^{* * *}$ & $\begin{array}{r}-2.80 \\
(0.31)\end{array}$ & $0.00^{* * *}$ & $\begin{array}{r}-3.68 \\
(0.55)\end{array}$ & $0.00^{* * *}$ & $\begin{array}{r}-3.57 \\
(0.31)\end{array}$ & $0.00^{* * *}$ & $\begin{array}{r}-2.80 \\
(0.28)\end{array}$ & $0.00^{* * *}$ & $\begin{array}{r}-6.49 \\
(1.22)\end{array}$ & $0.00^{* * *}$ \\
\hline Perf. decline & $\begin{array}{r}-0.07 \\
(0.03)\end{array}$ & $0.01^{* *}$ & $\begin{array}{r}-0.03 \\
(0.01)\end{array}$ & $0.06^{*}$ & $\begin{array}{r}-0.03 \\
(0.02)\end{array}$ & 0.21 & $\begin{array}{r}-0.04 \\
(0.01)\end{array}$ & $0.01^{* * *}$ & $\begin{array}{r}-0.03 \\
(0.01)\end{array}$ & $0.01^{* * *}$ & $\begin{array}{r}-0.01 \\
(0.05)\end{array}$ & 0.79 \\
\hline Sales growth & $\begin{array}{r}-0.04 \\
(0.05)\end{array}$ & 0.46 & $\begin{array}{c}0.14 \\
(0.03)\end{array}$ & $0.00^{* * *}$ & $\begin{array}{c}0.17 \\
(0.05)\end{array}$ & $0.00^{* * *}$ & $\begin{array}{c}0.06 \\
(0.03)\end{array}$ & $0.03^{* *}$ & $\begin{array}{c}0.05 \\
(0.03)\end{array}$ & $0.03^{* *}$ & $\begin{array}{c}0.07 \\
(0.08)\end{array}$ & 0.37 \\
\hline Leverage & $\begin{array}{r}-0.17 \\
(0.27)\end{array}$ & 0.52 & $\begin{array}{c}0.24 \\
(0.13)\end{array}$ & $0.07^{*}$ & $\begin{array}{l}0.26 \\
(0.25)\end{array}$ & 0.30 & $\begin{array}{l}0.11 \\
(0.15)\end{array}$ & 0.45 & $\begin{array}{r}-0.01 \\
(0.13)\end{array}$ & 0.93 & $\begin{array}{c}1.40 \\
(0.51)\end{array}$ & $0.01^{* * *}$ \\
\hline Free cash flow & $\begin{array}{r}-0.50 \\
(0.20)\end{array}$ & $0.01^{* *}$ & $\begin{array}{r}-0.03 \\
(0.11)\end{array}$ & 0.79 & $\begin{array}{c}0.06 \\
(0.20)\end{array}$ & 0.75 & $\begin{array}{r}-0.04 \\
(0.12)\end{array}$ & 0.77 & $\begin{array}{r}-0.03 \\
(0.10)\end{array}$ & 0.78 & $\begin{array}{r}-0.10 \\
(0.38)\end{array}$ & 0.78 \\
\hline Year effects & Yes & & Yes & & Yes & & Yes & & Yes & & Yes & \\
\hline Constant & $\begin{array}{r}-0.85 \\
(0.87)\end{array}$ & 0.33 & $\begin{array}{r}-5.34 \\
(0.47)\end{array}$ & $0.00^{* * *}$ & $\begin{array}{r}-5.80 \\
(0.99)\end{array}$ & $0.00^{* * *}$ & $\begin{array}{r}-4.09 \\
(0.48)\end{array}$ & $0.00^{* * *}$ & $\begin{array}{r}-4.26 \\
(0.45)\end{array}$ & $0.00^{* * *}$ & $\begin{array}{c}5.80 \\
(2.18)\end{array}$ & $0.01^{* * *}$ \\
\hline Observations & 1,662 & & 4,096 & & 1,295 & & 4,463 & & 4,835 & & 923 & \\
\hline \# of firms & 485 & & 935 & & 553 & & 1,175 & & 1,242 & & 528 & \\
\hline Within $R^{2}$ & 0.12 & & 0.11 & & 0.20 & & 0.10 & & 0.08 & & 0.22 & \\
\hline
\end{tabular}

Notes: Coefficients are reported with robust standard errors in parenthesis. $\mathrm{p}$ value is calculated based on two-tailed t statistics. ${ }^{*} \mathrm{p}<0.10 ;{ }^{* *} \mathrm{p}<0.05 ;{ }^{* * *} \mathrm{p}<0.01$ 
Table 5. Managerial slack and corporate governance mechanisms: Interaction models

\begin{tabular}{|c|c|c|c|c|c|c|c|c|}
\hline & \multicolumn{8}{|c|}{$\begin{array}{c}\text { Managerial Slack } \\
\text { Pooled OLS }\end{array}$} \\
\hline & (1) & $p$ value & (2) & $p$ value & (3) & p value & (4) & pvalue \\
\hline Final years $(\mathrm{H} 1)$ & $\begin{array}{c}0.08 \\
(0.03)\end{array}$ & $0.00^{* * *}$ & $\begin{array}{c}0.04 \\
(0.02)\end{array}$ & $0.01^{* * *}$ & $\begin{array}{c}0.14 \\
(0.06)\end{array}$ & $0.01^{* *}$ & $\begin{array}{c}0.18 \\
(0.06)\end{array}$ & $0.00^{* * *}$ \\
\hline $\begin{array}{l}\text { Final years } \times \mathrm{SOE} \\
\quad(\mathrm{H} 2)\end{array}$ & $\begin{array}{c}0.06 \\
(0.03)\end{array}$ & $0.05^{* *}$ & & & & & $\begin{array}{c}0.06 \\
(0.03)\end{array}$ & $0.05^{* *}$ \\
\hline $\begin{array}{l}\text { Final years } \times \text { CEO } \\
\text { Share }(\mathrm{H} 3)\end{array}$ & & & $\begin{array}{r}-0.01 \\
(0.03)\end{array}$ & & & & $\begin{array}{r}-0.02 \\
(0.03)\end{array}$ & 0.61 \\
\hline $\begin{array}{l}\text { Final years } \times \text { Indep } \\
\text { Board }(\mathrm{H} 4) \\
\end{array}$ & & & & & $\begin{array}{r}-0.12 \\
(0.05) \\
\end{array}$ & $0.02^{* *}$ & $\begin{array}{r}-0.12 \\
(0.06) \\
\end{array}$ & $0.05^{* *}$ \\
\hline Executive pay & $\begin{array}{c}0.04 \\
(0.02)\end{array}$ & $0.05^{* *}$ & $\begin{array}{c}0.04 \\
(0.02)\end{array}$ & $0.05^{*}$ & $\begin{array}{c}0.04 \\
(0.02)\end{array}$ & $0.05^{*}$ & $\begin{array}{c}0.04 \\
(0.02)\end{array}$ & $0.05^{*}$ \\
\hline SOE & $\begin{array}{c}0.09 \\
(0.03)\end{array}$ & $0.00^{* * *}$ & $\begin{array}{c}0.06 \\
(0.03)\end{array}$ & $0.04^{* *}$ & $\begin{array}{l}0.06 \\
(0.03)\end{array}$ & $0.03^{* *}$ & $\begin{array}{c}0.09 \\
(0.03)\end{array}$ & $0.01^{* * *}$ \\
\hline CEO share & $\begin{array}{c}0.01 \\
(0.02)\end{array}$ & 0.79 & $\begin{array}{c}0.01 \\
(0.03)\end{array}$ & 0.67 & $\begin{array}{c}0.00 \\
(0.02)\end{array}$ & 0.79 & $\begin{array}{c}0.01 \\
(0.03)\end{array}$ & 0.67 \\
\hline Indep. board & $\begin{array}{r}-0.01 \\
(0.04)\end{array}$ & 0.70 & $\begin{array}{r}-0.01 \\
(0.04)\end{array}$ & 0.70 & $\begin{array}{c}0.00 \\
(0.03)\end{array}$ & 0.49 & $\begin{array}{c}0.03 \\
(0.04)\end{array}$ & 0.45 \\
\hline Board size & $\begin{array}{r}-0.00 \\
(0.01)\end{array}$ & 0.67 & $\begin{array}{r}-0.00 \\
(0.01)\end{array}$ & 0.67 & $\begin{array}{r}-0.00 \\
(0.01)\end{array}$ & 0.68 & $\begin{array}{r}-0.00 \\
(0.01)\end{array}$ & 0.66 \\
\hline Combine & $\begin{array}{c}0.03 \\
(0.04)\end{array}$ & 0.36 & $\begin{array}{c}0.03 \\
(0.04)\end{array}$ & 0.35 & $\begin{array}{c}0.03 \\
(0.04)\end{array}$ & 0.35 & $\begin{array}{c}0.03 \\
(0.04)\end{array}$ & 0.36 \\
\hline Largest SH \% & $\begin{array}{r}-0.27 \\
(0.09)\end{array}$ & $0.00^{* * *}$ & $\begin{array}{r}-0.26 \\
(0.09)\end{array}$ & $0.00^{* * *}$ & $\begin{array}{r}-0.26 \\
(0.09)\end{array}$ & $0.00^{* * *}$ & $\begin{array}{r}-0.27 \\
(0.09)\end{array}$ & $0.00^{* * *}$ \\
\hline Big 10 auditor & $\begin{array}{c}0.01 \\
(0.03)\end{array}$ & 0.71 & $\begin{array}{l}0.01 \\
(0.03)\end{array}$ & 0.73 & $\begin{array}{c}0.01 \\
(0.03)\end{array}$ & 0.73 & $\begin{array}{c}0.01 \\
(0.03)\end{array}$ & 0.72 \\
\hline Total assets & $\begin{array}{c}0.18 \\
(0.02)\end{array}$ & $0.00^{* * *}$ & $\begin{array}{c}0.18 \\
(0.02)\end{array}$ & $0.00^{* * *}$ & $\begin{array}{c}0.18 \\
(0.02)\end{array}$ & $0.00^{* * *}$ & $\begin{array}{c}0.19 \\
(0.02)\end{array}$ & $0.00^{* * *}$ \\
\hline Return on assets & $\begin{array}{r}-2.12 \\
(0.41)\end{array}$ & $0.00^{* * *}$ & $\begin{array}{r}-2.11 \\
(0.41)\end{array}$ & $0.00^{* * *}$ & $\begin{array}{r}-2.21 \\
(0.41)\end{array}$ & $0.00^{* * *}$ & $\begin{array}{r}-2.10 \\
(0.41)\end{array}$ & $0.00^{* * *}$ \\
\hline Perf. decline & $\begin{array}{r}-0.11 \\
(0.02)\end{array}$ & $0.00^{* * *}$ & $\begin{array}{r}-0.11 \\
(0.02)\end{array}$ & $0.00^{* * *}$ & $\begin{array}{r}-0.10 \\
(0.02)\end{array}$ & $0.00^{* * *}$ & $\begin{array}{r}-0.10 \\
(0.02)\end{array}$ & $0.00^{* * *}$ \\
\hline Sales growth & $\begin{array}{r}-0.03 \\
(0.04)\end{array}$ & 0.39 & $\begin{array}{r}-0.03 \\
(0.04)\end{array}$ & 0.38 & $\begin{array}{r}-0.03 \\
(0.04)\end{array}$ & 0.37 & $\begin{array}{r}-0.03 \\
(0.04)\end{array}$ & 0.38 \\
\hline Leverage & $\begin{array}{r}-0.33 \\
(0.19)\end{array}$ & $0.09^{*}$ & $\begin{array}{r}-0.33 \\
(0.19)\end{array}$ & $0.09^{*}$ & $\begin{array}{r}-0.33 \\
(0.19)\end{array}$ & 0.09 & $\begin{array}{r}-0.33 \\
(0.19)\end{array}$ & $0.09^{*}$ \\
\hline Free cash flow & $\begin{array}{r}-0.11 \\
(0.16)\end{array}$ & 0.48 & $\begin{array}{r}-0.12 \\
(0.16)\end{array}$ & 0.48 & $\begin{array}{r}-0.12 \\
(0.16)\end{array}$ & 0.47 & $\begin{array}{r}-0.12 \\
(0.16)\end{array}$ & 0.47 \\
\hline $\begin{array}{l}\text { Year and industry } \\
\text { constant }\end{array}$ & $\begin{array}{c}\text { Yes } \\
-4.25 \\
(0.36) \\
\end{array}$ & $0.00^{* * *}$ & $\begin{array}{c}\text { Yes } \\
-4.22 \\
(0.36) \\
\end{array}$ & $0.00^{* * *}$ & $\begin{array}{c}\text { Yes } \\
-4.21 \\
(0.36) \\
\end{array}$ & $0.00^{* * *}$ & $\begin{array}{c}\text { Yes } \\
-4.25 \\
(0.36) \\
\end{array}$ & $0.00^{* * *}$ \\
\hline Observations & 5,758 & & 5,758 & & 5,758 & & 5,758 & \\
\hline $\operatorname{Adj} . R^{2}$ & 0.09 & & 0.09 & & 0.09 & & 0.09 & \\
\hline
\end{tabular}

Notes: Coefficients are reported with robust standard errors in parenthesis. p value is calculated based on two-tailed t statistics. ${ }^{*} \mathrm{p}<0.10 ;{ }^{* *} \mathrm{p}<0.05 ;{ }^{* * *} \mathrm{p}<0.01$.

of the interaction variable of SOE and 'Final Years'. Column 1 of Table 5 indicates that managerial slack increases $14 \%(0.08+0.06)$ when SOE CEOs approach turnover, compared to $8 \%$ for CEOs in non-SOEs. This difference is statistically significant at $\mathrm{p}=0.05$ level, thus supports the prediction of $\mathrm{H} 2$. 
Table 5 also suggests that firms with CEO equity ownership are associated with a lower level of managerial slack in CEO final years compared to firms without CEO equity ownership, although the difference is not statistically significant. Finally, table 5 indicates that firms with an independent board are associated with significantly smaller managerial slack in CEO final years. Column 3 indicates that although managerial slack increases $14 \%$ in final years of CEOs in firms without independent boards, firms with board independence are only associated with a milder $2 \%(0.14-0.12)$ increase in managerial slack. Generally speaking, our interaction models provide additional empirical supports for $\mathrm{Hl}$ on the presence of horizon problem and for $\mathrm{H} 2$ and $\mathrm{H} 4$ on the moderating roles of SOE and board independence.

\section{SENSITIVITY ANALYSIS}

\section{Alternative Measures of Managerial Slack}

We have shown in our main analyses that managerial slack increases during the CEO's final years in office and this relationship is further moderated by corporate governance designs. To evaluate whether our results are sensitive to alternative slack metrics, we re-estimate our main models using three alternative slack measures discussed earlier, namely (i) an asset scaled measure of abnormal G\&A expenditure, (ii) abnormal SG\&A expenses, and (iii) abnormal cash expense. For brevity we do not tabulate detailed results. Generally speaking, we find a clear and consistent picture that reinforces our main finding that there is a significant increase in managerial slack in CEO final years in office. For example, we find that managerial slack measured using the asset scaled method is significantly higher in CEO final years $(\beta=0.002$, se. $=0.000$, and $\mathrm{p}=0.00)$. Similarly, slack measured as abnormal SG\&A costs is also significantly higher in CEO final years $(\beta=$ 0.03 , se. $=0.01$, and $\mathrm{p}=0.00)$. Finally, a marginally significant coefficient is identified for slack measured using abnormal cash expense $(\beta=0.02$, se. $=0.01$, and $\mathrm{p}=0.09$ ). Our non-tabulated split-sample test results are also qualitatively consistent with empirical findings reported in Table 4, although significance levels of these results vary by measures. Taken as a whole, these additional tests confirm our main argument that managerial slack increases in Chinese CEOs' final years in office as a result of the horizon problem, and higher quality corporate governance mechanisms help mitigate the horizon effect manifested in managerial slack.

Apart from the residual method, the extant literature has also used voluntarily disclosed itemized expenditure to capture executive perks, a construct closely related to managerial slack captured in this study. We argue above that our residual measure is superior to this alternative measure. To further validate the appropriateness of our estimate, we also collect these voluntarily disclosed expenditure items reported in the appendix of firm financial reports following 
procedures described in Chen et al. (2016) and Gul et al. (2011). We define Perk_Chen as the logarithm of the summation of the eight itemized expenditures listed in Chen et al. (2016) and define Perk_Gul as the logarithm of the summation of the six itemized expenditures used by Gul et al. (2011). Given only a small proportion of our sample firms have disclosed these itemized expenses, we apply our residual method explained in Equation (1) to calculate managerial slack for all listed firms during our sample period of 2001 to 2011 regardless of their managerial turnover status. There is a total of 13,818 firm year observations that we have non-missing information to calculate managerial slack using the residual method. Within these firm years, we only obtain 4,475 firm-year observations for Perk_Chen and 4,204 observations for Perk_Gul. That is, only 30.42\% to $32.38 \%$ of firms have chosen to disclose detailed administrative expenditure, which validates our earlier claim that using voluntarily disclose information to measure managerial slack is subject to severe selection bias. We find that our measure of managerial slack is positively correlated with both Chen et al. (2016)'s and Gul et al. (2011)'s measures. The Pearson correlation between our measure and the Chen measure is 0.34 and for the Gul measure is 0.32 ; both significant at the 0.01 level. Thus, although different, our measure of managerial slack is in agreement with these alternatives proposed in prior literature. We thus conclude that our measure does possess external validity.

\section{Managerial Slack and Firm Performance}

If an increase in managerial slack is a result of an optimal compensation design or valuable resources for innovation and change, we should expect a positive relationship between managerial slack and firm performance. That is, if managerial slack is beneficial to the firm, an increase in managerial slack should be associated with higher firm performance and an increase in shareholder wealth. Is this claim true? To evaluate this counter argument, we test the performance impact of managerial slack and report our results in Table 6. We estimate firm performance equations using both an accounting performance measure of the return on assets ratio denoted as 'ROA' and a stock performance measure of annualized stock returns denoted as 'RET'. To prevent the problem of reverse causality and the possible mechanical relationship between our slack measure (abnormal G\&A expenditure) and the current-term accounting performance measure, we lag all our independent variables by one year to test the influence of managerial slack on the next period firm performance. Columns 1 and 3 are based on the whole sample of all listed firms between 2001 and 2011; columns 2 and 4 report results from our CEO turnover sample applied in the main analysis. All estimates are conducted using the firm-level fixed effects regression method.

Table 6 indicates a consistently significant negative relationship between managerial slack and firm performance measured using both ROA and stock 
Table 6. Managerial slack and firm performance

\begin{tabular}{|c|c|c|c|c|c|c|c|c|}
\hline & \multicolumn{4}{|c|}{$\begin{array}{c}R O A_{t+1} \\
\text { Fixed effects }\end{array}$} & \multicolumn{4}{|c|}{$\begin{array}{l}R_{E} T_{t+1} \\
\text { Fixed effects }\end{array}$} \\
\hline & $\begin{array}{c}\text { Whole } \\
\text { Sample } \\
\text { (1) }\end{array}$ & $p$ value & $\begin{array}{c}\text { Main } \\
\text { Sample } \\
\text { (2) }\end{array}$ & $p$ value & $\begin{array}{c}\text { Whole } \\
\text { Sample } \\
\text { (3) }\end{array}$ & $p$ value & $\begin{array}{c}\text { Main } \\
\text { Sample } \\
\text { (4) }\end{array}$ & $p$ value \\
\hline Managerial slack & $\begin{array}{r}-0.00 \\
(0.00) \\
\end{array}$ & $0.00^{* * *}$ & $\begin{array}{r}-0.00 \\
(0.00) \\
\end{array}$ & $0.05^{* *}$ & $\begin{array}{r}-0.08 \\
(0.02) \\
\end{array}$ & $0.00^{* * *}$ & $\begin{array}{r}-0.11 \\
(0.03) \\
\end{array}$ & $0.00^{* * *}$ \\
\hline Executive pay & $\begin{array}{c}0.01 \\
(0.00)\end{array}$ & $0.00^{* * *}$ & $\begin{array}{c}0.01 \\
(0.00)\end{array}$ & $0.00^{* * *}$ & $\begin{array}{r}-0.09 \\
(0.02)\end{array}$ & $0.00^{* * *}$ & $\begin{array}{r}-0.04 \\
(0.03)\end{array}$ & 0.21 \\
\hline SOE & $\begin{array}{r}-0.01 \\
(0.00)\end{array}$ & $0.00^{* * *}$ & $\begin{array}{r}-0.01 \\
(0.00)\end{array}$ & $0.03^{* *}$ & $\begin{array}{r}-0.15 \\
(0.03)\end{array}$ & $0.00^{* * *}$ & $\begin{array}{r}-0.17 \\
(0.06)\end{array}$ & $0.01^{* * *}$ \\
\hline CEO share & $\begin{array}{c}0.00 \\
(0.01)\end{array}$ & 0.83 & $\begin{array}{l}0.00 \\
(0.03)\end{array}$ & 0.85 & $\begin{array}{c}0.53 \\
(0.29)\end{array}$ & $0.06^{*}$ & $\begin{array}{l}0.77 \\
(0.52)\end{array}$ & 0.14 \\
\hline Indep. board & $\begin{array}{c}0.00 \\
(0.00)\end{array}$ & $0.07^{*}$ & $\begin{array}{l}0.00 \\
(0.00)\end{array}$ & 0.34 & $\begin{array}{c}0.35 \\
(0.02)\end{array}$ & $0.00^{* * *}$ & $\begin{array}{l}0.28 \\
(0.04)\end{array}$ & $0.00^{* * *}$ \\
\hline Board size & $\begin{array}{r}-0.00 \\
(0.00)\end{array}$ & $0.00^{* * *}$ & $\begin{array}{r}-0.00 \\
(0.00)\end{array}$ & 0.55 & $\begin{array}{r}-0.02 \\
(0.01)\end{array}$ & $0.00^{* * *}$ & $\begin{array}{r}-0.03 \\
(0.01)\end{array}$ & $0.00^{* * *}$ \\
\hline Combine & $\begin{array}{r}-0.00 \\
(0.00)\end{array}$ & 0.35 & $\begin{array}{c}0.00 \\
(0.00)\end{array}$ & 0.81 & $\begin{array}{c}0.02 \\
(0.03)\end{array}$ & & $\begin{array}{c}0.04 \\
(0.04)\end{array}$ & 0.40 \\
\hline Largest SH\% & $\begin{array}{c}0.03 \\
(0.00)\end{array}$ & $0.00^{* * *}$ & $\begin{array}{l}0.03 \\
(0.01)\end{array}$ & $0.00^{* * *}$ & $\begin{array}{r}-1.26 \\
(0.08)\end{array}$ & $0.00^{* * *}$ & $\begin{array}{r}-1.61 \\
(0.16)\end{array}$ & $0.00^{* * *}$ \\
\hline Big 10 auditor & $\begin{array}{c}0.00 \\
(0.00)\end{array}$ & 0.51 & $\begin{array}{r}-0.00 \\
(0.00)\end{array}$ & 0.69 & $\begin{array}{r}-0.11 \\
(0.02)\end{array}$ & $0.00^{* * *}$ & $\begin{array}{c}0.01 \\
(0.04)\end{array}$ & 0.81 \\
\hline Log assets & $\begin{array}{r}-0.01 \\
(0.00)\end{array}$ & $0.00^{* * *}$ & $\begin{array}{r}-0.01 \\
(0.00)\end{array}$ & $0.00^{* * *}$ & $\begin{array}{c}0.05 \\
(0.02)\end{array}$ & $0.02^{* *}$ & $\begin{array}{l}0.17 \\
(0.04)\end{array}$ & $0.00^{* * *}$ \\
\hline Sales growth & $\begin{array}{c}0.02 \\
(0.00)\end{array}$ & $0.00^{* * *}$ & $\begin{array}{c}0.02 \\
(0.00)\end{array}$ & $0.00^{* * *}$ & $\begin{array}{c}0.10 \\
(0.03)\end{array}$ & $0.00^{* * *}$ & $\begin{array}{l}0.09 \\
(0.05)\end{array}$ & $0.06^{*}$ \\
\hline Leverage & $\begin{array}{r}-0.02 \\
(0.01)\end{array}$ & $0.00^{* * *}$ & $\begin{array}{r}-0.01 \\
(0.01)\end{array}$ & 0.43 & $\begin{array}{c}0.06 \\
(0.14)\end{array}$ & 0.69 & $\begin{array}{l}0.20 \\
(0.25)\end{array}$ & 0.42 \\
\hline Year effects & Yes & & Yes & & Yes & & Yes & \\
\hline Constant & $\begin{array}{c}0.13 \\
(0.02) \\
\end{array}$ & $0.00^{* * *}$ & $\begin{array}{c}0.25 \\
(0.03) \\
\end{array}$ & $0.00^{* * *}$ & $\begin{array}{c}0.74 \\
(0.39) \\
\end{array}$ & $0.05^{*}$ & $\begin{array}{r}-2.14 \\
(0.75) \\
\end{array}$ & $0.00^{* * *}$ \\
\hline Observations & 11,844 & & 5,571 & & 11,844 & & 5,571 & \\
\hline \# of firms & 1,692 & & 1,254 & & 1,692 & & 1,254 & \\
\hline Within $R^{2}$ & 0.05 & & 0.05 & & 0.06 & & 0.07 & \\
\hline
\end{tabular}

Notes: Coefficients are reported with robust standard errors in parenthesis. $\mathrm{p}$ value is calculated based on two-tailed t statistics. ${ }^{*} \mathrm{p}<0.10{ }^{* *} \mathrm{p}<0.05{ }^{* * *} \mathrm{p}<0.01$.

market returns in both the whole sample and our CEO turnover sample. That is, larger managerial slack is associated with worse firm accounting performance and worse stock market returns as predicted by agency theory. These results testify our construct validity, i.e. managerial slack captured in our article reflects managerial excess that reduces value of Chinese listed firms. ${ }^{[6]}$

\section{DISGUSSION}

Our research is motivated by Williamson (1964)'s managerial discretion model that defines managerial slack as excess costs, compensation, and perks consumed by 
management at their own discretion to divert firm resources from other productive activities. We add a temporal dimension to the concept of managerial slack to investigate the impact of the horizon problem on managerial slack. We test whether there is a disproportional increase in managerial slack prior to CEO turnover. Using data on Chinese listed firms experiencing CEO turnovers between 2003 and 2011, we find consistent evidence that managerial slack is significantly higher during the CEO's final years in office. This empirical evidence is consistent with the predicted horizon effect, i.e., CEOs modify their behavior later in their careers to gain private benefits at the cost of shareholder interests. In addition, we find that the increase in managerial slack at the time of CEO departure is larger in SOEs, but smaller in firms with CEO equity ownership and independent boards. These results suggest that corporate governance mechanisms help alleviate the horizon problem manifested in managerial slack and improve operational efficiency. Our results are also robust to alternative measures of managerial slack and a refined measure of CEO turnover. Finally, our additional analysis documents a consistently negative relationship between managerial slack and firm performance and confirms that slack captured in our paper is indeed a reflection of managerial diversion and organizational inefficiency since it reduces instead of enhances firm value.

From a theoretical standpoint, our findings provide new insights to the CEO horizon problem. The extant literature on the horizon effect is rooted in the work of agency theory and behavioral models on myopic decision-making and risk aversion (Fama, 1980; Kahneman \& Tversky, 1979). It also falls in the broadly defined economic short-termism (Laverty, 1996) and managerial temporal myopia (Miller, 2002). The short-term temporal horizon compels executives to operate with a short-run perspective, since they are unable to benefit much from longterm firm profitability. As a result, the horizon effect would nudge CEOs to reduce investment with long-term payoffs in an attempt to boost short-term earnings and to maximize their post-turnover or post-retirement incomes (Krause \& Semadeni, 2014; Matta \& Beamish, 2010; McClelland, Liang, \& Barker III, 2010; McClelland et al., 2012). We significantly augment this stream of studies to test a new process variable, namely operational efficiency manifested in the level of managerial slack. We argue that when the managerial labor market is less efficient in assessing and rewarding CEO performance, the horizon problem may result in increased operational inefficiency and accentuated managerial slack in the years near CEO exits instead of prompting CEOs to increase short-term performance at the cost of long-term benefits. More specifically, at presence of an embryonic corporate governance system and a relatively primitive executive labor market, the myopic focus induced by anticipated job separation may motivate departing CEOs to shirk their duties or to directly divert firm resource so as to maximize their short-term gains. This is because long-term penalties associated with such value-diminishing activities are limited and negligible. By testing the horizon effect in a major emerging market, we determine and highlight an alternative consequence of the 
CEO horizon effect, mainly its impact on operational efficiency and managerial slack.

We also provide an important methodological contribution to the study of organizational slack. While it has long been realized that slack can have both positive and negative effects on firm performance, management studies to date have mainly focused on examining the performance impact of slack and identifying contingency factors that may affect the relationship between slack and firm performance (e.g., Ju \& Zhao, 2009; McClelland et al., 2012; Peng, Li, Xie, \& Su, 2010; Singh, 1986; Su, Xie, \& Li, 2009; Tan \& Peng, 2003). It has consequently been suggested that there is an optimal level of slack and the relationship between slack and firm performance is curvilinear with the negative effect starting to dominate when slack exceeds certain amounts or when organizational characteristics are not favorable for efficient deployment of slack resource. We tackle the double-edged role of slack by measuring managerial slack as excess general administrative expenses expressed as a deviation from the predicted optimal level of slack. Effectively, we introduce to the managerial slack literature a new technique (i.e., residual analysis) to isolate managerial private benefits from the aggregate slack measure adopted in prior studies. The promulgation of this residual method thus enables us to explicitly separate the positive component of slack owing to legitimate investment and diligent deployment of firm resources from the negative element that likely reflects organizational inefficiency and managerial diversion of productive assets.

The findings of our study also have practical implications. First, our study points to the significance of situational and structural factors in affecting the magnitude of horizon problem and managerial slack. For example, our study highlights the importance of executive equity incentives as a potential alignment tool to alleviate the horizon problem at the later stage of managerial careers. Our study also indicates that enhanced board independence is effective in mitigating the negative impact of CEO horizon problem on managerial slack. This is reassuring for advocates of 'best-practice' corporate governance methods, since regulatory changes that improve corporate governance quality appear to have a positive impact on shareholder value. We argued earlier that the problem of managerial slack is particularly severe in China given its relatively weak financial disclosure system that creates substantial information asymmetry between management and shareholders. Recent studies in the US have indicated that enhanced disclosure rules imposed by Securities and Exchange Commission (SEG) in 2006 lead to disclosures of significantly larger amounts of perquisites and a substantial reduction in these discretionary expenses afterwards (Grinstein, Weinbaum, \& Yehuda, 2017). We thereby suggest that imposing more extensive financial disclosure rules might be a reasonable policy direction to better constrain managerial value diversion and improve operational efficiency.

Our article also suggests several future directions for research. First, Meyer (2015) suggests that it is essential to incorporate national contexts in management 
research to set boundary conditions for a theoretical model. A natural extension to our study is to investigate similar research topics in other countries, cultures, and contexts to probe whether managerial slack is also affected by the impending departure of key executives, or to conduct a cross-country comparative study to examine contingency factors affecting the magnitude of such impacts. Second, we have probed the importance of internal corporate governance mechanisms as a means to ameliorate the influence of horizon problem on managerial slack. Future research might focus on the efficacy of external governance mechanisms and the overall governance environment in controlling managerial opportunism and temporal myopia. Finally, our article has suggested that managerial time horizon has a significant impact on their decision-making outcomes in terms of the level of managerial slack. Future studies may benefit from extending this stream of literature to further explore the role of time horizon and temporal orientation in affecting resource allocation, strategic choices, and other organizational outcomes (Reilly, Souder, \& Ranucci, 2016).

\section{GONCLUSION}

Overall, our paper provides the first evidence on the existence of a horizon effect for Chinese CEOs during their final years in office as reflected in higher operational inefficiency and larger managerial slack. We also identify the moderating role of internal corporate governance mechanisms in curtailing the severity of the horizon problem. Although our study is conducted in the Chinese context, it will also have implications for other emerging economies with institutional voids. We hope that our findings could enhance understanding on managerial myopia and stimulate further research on the effectiveness of corporate governance mechanisms in mitigating executive short-termism and promoting shareholder value in China and beyond.

\section{NOTES}

We thank Alex Bryson, Jerry Cao, Peter Cappelli, Richard Freeman, Donald Hambrick, Jianqiao Hong, William Judge, Kenneth Kim, Clive Lennox, Yunguo Liu, Changjiang Lv, Gary Tian, Lixin Colin Xu, Hongqi Yuan, Zhifang Zhang, and seminar participants at the 2012 International Workshop on CEO Compensation, Corporate Governance, and Firm Performance, the 2012 Financial Young Scholar Round Table Seminar, the 2014 Academy of Management Annual Meeting, and the 2015 Inaugural International Corporate Governance Society Annual Conference for comments on earlier versions of this paper. We would also like to thank Senior Editor Dr. Xiaowei Luo and two anonymous reviewers for their insights. This research was supported by three grants from National Natural Science Foundation of China: 'Government Control, Marketization and the Efficiency of Top Management Compensation Contract in China' (71072003), 'Institutional Environment, Corporate Governance and CEO Governance' (71372119), and 'Information Disclosure and Market Competition under Informaton Asymmetry: Theory, Evidence and Policy' (71673048). Financial support from the $4^{\text {th }}$ Fujian 100 Innovation \& Entrepreneurship Grant (He) and Center for Human Resources at the Wharton School (Conyon) are also gratefully acknowledged. 
[1] The use of the job title, Chief Executive Officer, or GEO to identify the most senior firm executive is a relatively new phenomenon in China. Only recently are Chinese companies beginning to use this term. Historically, General Manager has been used to represent presidents of a company. In addition, the Chairman of the board of directors in China is the legal representative of the firm who works full time for the company, thus it is also a top executive position that ranks even above the general manager (Firth et al., 2006). Previous Chinese corporate governance literature either used the general manager or the chairperson of the board, or a combination of these two positions to represent CEOs. In our study, we code CEO turnover as one whenever the general manager or the chairperson leaves the position and the firm, but not when the person relinquishes one post and remains another.

[2] This measure is constructed based on Fan, Wang, and Zhu (2011)'s NERI index, which is an annual index created for each of the 31 Chinese provinces as well as four municipalities directly under control of the central administration. We code 'Developed' as one if the firm's headquarter is located in a region with above median NERI market development score.

[3] Chen et al. (2016) identify eight items related to executive perks using voluntarily disclosed expenditure, including 1) office expenses, 2) business travel expenses, 3) business entertainment expenses, 4) communication expenses, 5) training expenses, 6) board meeting expenses, 7) company car expense, and 8) meeting expenses. Gul et al. (2011) excluded office expenses and communication expenses from the above list and used the remaining six items to measure executive perk.

[4] We follow He and Fang (2016) to classify a turnover as a forced one if the turnover reason is dismissal, litigation, retirement before 60 , personal reasons, or no reason given. It is classified as voluntary in all other cases. Data on such classifications are provided by CSMAR.

[5] Due to a more primitive compensation disclosure system, Chinese listed firms were not required to report individual executive compensation information before 2005, but only had to report the aggregate compensation of the top three highest paid executives. As a result, we use this average compensation number to conduct our analysis following some prior Chinese executive compensation studies (e.g., Firth et al., 2006, Conyon \& He, 2011). In our unreported tables, we also substitute this measure with abnormal executive compensation measured using the residual method by subtracting the predicted normal level of executive compensation from total executive compensation following He and Fang (2016)'s study. Our results from this alternative compensation measure are qualitatively consistent with those reported using the main measure.

[6] We also perform other additional analyses. To rule out reverse causality that excessive consumption of managerial slack may induce disciplinary actions from the firm and subsequently cause CEO turnover, we test the relationship between managerial slack and the likelihood of forced turnover by running a Probit regression of CEO forced turnover on all four measures of managerial slack specified above. Consistent with the extant CEO turnover literature, we do document a significant negative relationship between firm performance and the likelihood of forced executive turnover (e.g., Kato \& Long, 2006; Shen \& Lin, 2009). We, however, do not find a significant positive linkage between our measures of managerial slack and the likelihood of forced CEO turnover. These findings again support our earlier claim that managerial slack in CEO final years could be attributed to the horizon problem. Detailed results are available on request. 


\section{APPENDIX I}

\section{The Residual Model to Calculate Managerial Slack}

\begin{tabular}{|c|c|c|c|c|}
\hline \multirow[b]{2}{*}{ Variables } & \multicolumn{4}{|c|}{$\log \left(G \mathcal{E}^{2} A_{i, t}\right)$} \\
\hline & Coefficient & Robust Std. Err & $t$ stat. & $p$ value \\
\hline $\log \left(\right.$ Sales $\left._{\mathrm{it}}\right)$ & 0.44 & $(0.01)$ & $(44.37)$ & $0.00^{* * *}$ \\
\hline $\mathrm{PPE}_{\mathrm{it}} / \mathrm{Asset}_{\mathrm{it}}$ & 0.24 & $(0.07)$ & $(3.32)$ & $0.00^{* * *}$ \\
\hline Emp_Intensity & 56.81 & (78.88) & $(0.72)$ & 0.47 \\
\hline Asset_Intensity & -0.00 & $(0.00)$ & $(-0.66)$ & 0.51 \\
\hline Adv_Intensity & 1.95 & $(0.47)$ & $(4.19)$ & $0.00^{* * *}$ \\
\hline R\&D_Intensity ${ }_{i t}$ & 3.05 & $(0.51)$ & $(5.99)$ & $0.00^{* * *}$ \\
\hline Sales_Growth & -0.37 & $(0.02)$ & $(-15.56)$ & $0.00^{* * *}$ \\
\hline Sales_Decrease $_{i t}$ & 0.11 & $(0.01)$ & $(8.08)$ & $0.00^{* * *}$ \\
\hline Return $_{\text {it }}$ & -0.01 & $(0.00)$ & $(-1.68)$ & $0.09^{*}$ \\
\hline Cross_listing $_{\text {it }}$ & 0.22 & $(0.04)$ & $(5.69)$ & $0.00^{* * *}$ \\
\hline Developed $_{\text {it }}$ & -0.04 & $(0.03)$ & $(-1.63)$ & 0.10 \\
\hline Industry Dummy & Yes & & & \\
\hline Year Dummy & Yes & & & \\
\hline Constant & 8.89 & $(0.21)$ & $(41.85)$ & $0.00^{* * *}$ \\
\hline Observations & 13,818 & & & \\
\hline $\operatorname{Adj} . R^{2}$ & 0.57 & & & \\
\hline
\end{tabular}

Notes: Detailed Models are specified in Equation 1. Coefficients are reported along with robust standard errors and $\mathrm{t}$ statistics in parenthesis. ${ }^{*} \mathrm{p}<0.10 ;{ }^{* *} \mathrm{p}<0.05 ;{ }^{* * *} \mathrm{p}<.0 .01$.

\section{REFERENGES}

Adithipyangkul, P., Alon, I., \& Zhang, T. 2011. Executive perks: Compensation and corporate performance in China. Asia Pacific Journal of Management, 28(2): 401-425.

Anderson, M., Banker, R., Huang, R., \& Janakiraman, S. 2007. Cost behavior and fundamental analysis of SG\&A costs. Journal of Accounting, Auditing, and Finance, 22(1): 1-28.

Antia, M., Pantzalis, C., \& Park, J. C. 2010. CEO decision horizon and firm performance: An empirical investigation. Journal of Corporate Finance, 16(3): 288-301.

Banker, R., Huang, R., \& Natarajan, R. 2011. Equity incentives and long-term value created by SG\&A expenditure. Contemporary Accounting Research, 28(3): 794-830.

Barker, V. L. III., \& Mueller, G. 2002. CEO characteristics and firm R\&D spending. Management Science, 48(6): 782-801.

Bebchuk, L., \& Jolls, G. 1999. Managerial value diversion and shareholder wealth. Journal of Laze, Economics, and Organization, 15(2): 487-502.

Bebchuk, L., \& Stole, L. 1993. Do short-term objectives lead to under- or over-investment in long term projects. Journal of Finance, 48(2): 719-729.

Boyd, B. 1994. Board control and CEO compensation. Strategic Management Journal, 15(5): 335-344.

Brickley, J., Linck, J., \& Coles, J. 1999. What happens to CEOs after they retire? New evidence on career concerns, horizon problems, and CEO incentives. Journal of Financial Economics, 52(3): 341-377.

Cai, D., Luo, J., \& Wan, D. 2012. Family CEOs: Do they benefit firm performance in China? Asia Pacific Journal of Management, 29(4): 923-947.

Cai, H., Fang, H., \& Xu, L. 2011. Eat, drink, firms, government: An investigation of corruption from the entertainment and travel costs of Chinese firms. Journal of Laze and Economics, 54(1): $55-78$. 
Casamatta, C., \& Guembel, A. 2010. Managerial legacies, entrenchment, and strategic inertia. Journal of Finance, 65(6): 2403-2436.

Chang, E., \& Wong, S. 2009. Governance with multiple objectives: Evidence from top executive turnover in China. Journal of Corporate Finance, 15(2): 230-244.

Chen, D., Li, O., \& Liang, S. 2016. Perk consumption as a suboptimal outcome under pay regulations. Asia-Pacific Journal of Accounting and Economics, 23(4): 373-399.

Chen, J., Cumming, D., Hou, W., \& Lee, E. 2016. CEO accountability for corporate fraud: Evidence from the split share structure reform in China.Journal of Business Ethics, 138(4): 787-806.

Chen, X., Lu, H., \& Sougiannis, T. 2012.The agency problem, corporate governance, and the asymmetrical behavior of selling, general, and administrative costs. Contemporary Accounting Research, 29(1): 252-282.

Cheng, J., \& Kesner, I. 1997. Organizational slack and response to environmental shifts: The impact of resource allocation patterns. Journal of Management, 23(1): 1-18.

Conyon, M., \& Florou, A. 2006. The pattern of investment surrounding CEO retirements: UK evidence. British Accounting Revieze, 38(3): 299-319.

Conyon, M., \& He, L. 2011. Executive compensation and corporate governance in China.Journal of Corporate Finance, 17(4): 1158-1175.

Conyon, M., \& He, L. 2012. CEO pay and corporate governance in China. Corporate Governance: An International Revieze, 20(6): 575-592.

Conyon, M., \& He, L. 2016. Executive compensation and corporate fraud in China.Journal of Business Ethics, 134(4): 669-691.

Cyert, R., \& March, J. 1963. A behavioral theory of the firm. Englewood Cliffs, NJ: PrenticeHall.

Dalton, D., Daily, C., Ellstrand, A., \& Johnson, J. 1998. Meta-analytic reviews of board composition, leadership structure, and financial performance. Strategic Management Journal, 19(3): 269-290.

Davis, G. 2005. New directions in corporate governance. Annual Revieze of Sociology, 31(1): $143-162$.

Dechow, P., \& Sloan, R. 1991. Executive incentives and the horizon problem: An empirical investigation. Journal of Accounting and Economics, 14(1): 51-89.

DeFond, M. L., Wong, T. J., \& Li, S. 2000. The impact of improved auditor independence on audit market concentration in China. Journal of Accounting and Economics, 28(3): 269-305.

Delios, A., Wu, Z. J., \& Zhou, N. 2006. A new perspective on ownership identities in China's listed companies. Management and Organization Revieze, 2(3): 319-343.

Ding, Y., Zhang, H., \& Zhang, J. 2007. Private vs. state ownership and earnings management: Evidence from Chinese listed companies. Corporate Governance: An International Revieze, 15(2): 223-238.

Fama, E. 1980. Agency problems and the theory of the firm. Journal of Political Economy, 88(2): 288-307.

Fan, G., Wang, X., \& Zhu, H. 2011. NERI index of marketization of China's provinces: 2011 report. Beijing, Economic Science Press.

Feng, M., Li, C., \& McVay, S. 2009. Internal control and management guidance. Journal of Accounting and Economics, 48(2-3): 190-209.

Ferris, S., Kim, K., \& Noronha, G. 2009. The effect of crosslisting on corporate governance: A review of the international evidence. Corporate Governance: An International Revieze, 17(3): $338-352$.

Finkelstein, S., Hambrick, D. C., \& Cannella, A. 2009. Strategic leadership: Theory and research on executives, top management teams, and boards. New York: Oxford University Press.

Firth, M., Fung, P., \& Rui, O. 2006. Firm performance, governance structure, and top management turnover in a transitional economy.Journal of Management Studies, 43(6): 1289-1330.

Firth, M., Fung, P., \& Rui, O. 2007. How ownership and corporate governance influence chief executive pay in China's listed firms. Journal of Business Research, 60(7): 776-785.

Firth, M., Wong, S., \& Xin, Q. 2016. Regulatory sanctions on independent directors and their consequences to the director labor market: Evidence from China. Journal of Business Ethics, 134(4): 693-708.

Gibbons, R., \& Murphy, K. 1992. Optimal incentive contracts in the presence of career concerns: Theories and evidence. Journal of Political Economy, 100(3): 468-506. 
Grinstein, Y., Weinbaum, D., \& Yehuda, N. 2017. The economic consequences of perk disclosure. Contemporary Accounting Research, DOI: 10.1111/1911-3846.12343.

Gul, F., Cheng, L., \& Leung, T. 2011. Perks and the informativeness of stock prices in the Chinese market. Journal of Corporate Finance, 17(5): 1410-1429.

Hambrick, D. C., \& Mason, P. 1984. Upper echelons: The organization as a reflection of its top managers. Academy of Management Revieze, 9(2): 193-206.

Hart, O. 1983. The market mechanism as an incentive scheme. Bell Journal of Economics, 14(2): 366-382.

Haveman, H. A., \& Wang, Y. 2013. Going (more) public: Institutional isomorphism and ownership reform among Chinese firms. Management and Organization Revieze, 9(1): 17-51.

He, L., \& Fang, J. 2016. CEO overpayment and dismissal: The role of attribution and attention. Corporate Governance: An International Revieze, 24(1): $24-41$.

He, L., Shaw, T., \& Fang, J. 2017. Managerial labor market during institutional transition: A study of CEO underpayment and voluntary turnover. Corporate Governance: An International Review, 25(3): 167-185.

Hermalin, B. E., 1992. The effects of competition on executive behavior. Rand Journal of Economics, 23(3): 350-365.

Hermalin, B. E., \& Weisbach, M. S. 1988. The determinants of board composition. Rand Journal of Economics, 19(4): 589-606.

Huson, M. R., Tian, Y., Wiedman, C., \& Wier, H. 2012. Compensation committees' treatment of earnings components in CEOs' terminal years. The Accounting Review, 87(1): 231-259.

Jensen, M. 1986. Agency costs of free cash flow, corporate finance, and takeovers. American Economic Revieze, 76(2): 323-329.

Jensen, M. 1993. The modern industrial revolution, exit and the failure of internal control systems. Journal of Finance, 48(3): 831-880.

Jensen, M., \& Meckling, W. 1976. Theory of the firm: Managerial behavior, agency costs and ownership structure. Journal of Financial Economics, 3(4): 305-360.

Jensen, M., \& Murphy, K.J. 1990. Performance pay and top-management incentives. Journal of Political Economy, 98(2): 225-264.

Jensen, M., \& Warner, J. B. 1988. The distribution of power among corporate managers, shareholders, and directors. Journal of Financial Economics, 20(1-2): 3-24.

Ju, M., \& Zhao, H. 2009. Behind organizational slack and firm performance in China: The moderating roles of ownership and competitive intensity. Asia Pacific Journal of Management, 26(4): 701-717.

Kahneman, D., \& Tversky, A. 1979. Prospect theory: Analysis of decision under risk. Econometrica, 47(2): 263-291.

Kato, T., \& Long, C. 2006. Executive turnover and firm performance in China. American Economic Revieze, 96(2): 363-367.

Kornai, J., Maskin, E., \& Roland, G. 2003. Understanding the soft budget constraint. Journal of Economic Literature, 41(4): 1095-1136.

Krause, R., \& Semadeni, M. 2014. Last dance or second chance? Firm performance, CEO career horizon, and the separation of board leadership roles. Strategic Management Journal, 35(6): 808-825.

Laverty, K. 1996. Economic 'short-termism': The debate, the unresolved issues, and the implications for management practice and research. Academy of Management Review, 21(3): 825-860.

Li, S., Xia, J., Long, C., \& Tan, J. 2012. Control modes and outcomes of transformed state owned enterprises in China: An empirical test. Management and Organization Revieze, 8(2): 283-309.

Lott, J. R.Jr. 1990. Attendance rates, political shirking, and the effect of post-elective office employment. Economic Inquiry, 28(1): 133-150.

Luo, W., Zhang, Y., \& Zhu, N. 2011. Bank ownership and executive perquisites: New evidence from an emerging market. Journal of Corporate Finance, 17: 352-270.

March, J., \& Simon, H. 1958. Organizations. New York: Wiley.

Martin, G., Wiseman, R., \& Gomez-Mejia, L. 2016. Going short-term or long-term? CEO stock options and temporal orientation in the presence of slack. Strategic Management Journal, 37(12): 2463-2480.

Matejka, M., Merchant, K., \& Stede, W. 2009. Employment horizon and the choice of performance measures: Empirical evidence from annual bonus plans of loss-making entities. Management Science, 55(6): 890-905. 
Matta, E., \& Beamish, P. 2008. The accentuated CEO career horizon problem: Evidence from international acquisitions. Strategic Management Journal, 29(7): 683-700.

McClelland, P. L., Barker, V. III, \& Oh, W. 2012. CEO career horizon and tenure: Future performance implications under different contingencies. Journal of Business Research, 65: 1387-1393.

McClelland, P. L., Liang, X., Barker, V. III. 2010. CEO commitment to the status quo: replication and extension using content analysis.Journal of Management, 36(5): 1251-1277.

Miller, 2002. Knowledge inventories and managerial myopia. Strategic Management Journal, 29(3): 273-292.

Meyer, K. 2015. Context in management research in emerging economies. Management and Organization Revieze, 1 1(3): 369-377.

Murphy, K.J., \& Zimmerman, J. L. 1993. Financial performance surrounding CEO turnover. Journal of Accounting and Economics, 16(1-3): 273-315.

Narayanan, M. P. 1987. Managerial incentives for short-term results: A reply.Journal of Finance, 42(4): 1103-1104.

Peng, M. 2003. Institutional transitions and strategic choices. Academy of Management Revieze, 28(2): 275-296.

Peng, M., Li, Y., Xie, E., \& Su, Z. 2010. CEO duality, organizational slack, and firm performance in China. Asia Pacific Journal of Management, 27(4): 611-624.

Reilly, G., Souder, D., \& Ranucci, R. 2016. Time horizon of investments in the resource allocation process: Review and framework for next steps. Journal of Management, 42(5): 1169-1194.

Scharfstein, D. 1988. Product-market competition and organizational slack. Rand Journal of Economics, 19(1): 147-155.

Shen, W., \& Lin, C. 2009. Firm profitability, state ownership, and top management turnover at the listed firms in China: A behavioral perspective. Corporate Governance: An International Revieze, 17(4): 443-456.

Shen, W., Zhou, Q., \& Lau, C. 2016. Empirical research on corporate governance in China: A review and new directions for the future. Management and Organization Revieze, 12(1): 41-73.

Shleifer, A., \& Vishny, R. 1997. A survey of corporate governance. Journal of Finance, 52(2): $737-77$.

Singh, J. 1986. Performance, slack, and risk taking in organizational decision making. Academy of Management Journal, 29(3): 562-585.

Souder, D., \& Shaver, M. 2010. Constraints and incentives for making long horizon corporate investments. Strategic Management Journal, 31(12): 1316-1336.

Stan, C., Peng, M., \& Bruton, G. 2014. Slack and the performance of state-owned enterprises. Asia Pacific Journal of Management, 31(2): 473-495.

Su, Y. Y., Xu, D., \& Phan, P. H. 2008. Principal-principal conflict in the governance of the Chinese public corporation. Management and Organization Revieze, 4(1): 17-38.

Su, Z., Xie, E., \& Li, Y. 2009. Organizational slack and firm performance during institutional transition. Asia Pacific Journal of Management, 26(1): 75-91.

Tan, J., \& Peng, M. 2003. Organizational slack and firm performance during economic transitions: Two studies from an emerging economy. Strategic Management Journal, 24(13): 1249 1263.

Weisbach, M. S. 1988. Outside directors and CEO turnover.Journal of Financial Economics, 20: $431-460$.

Williamson, O. 1964. The economics of discretionary behavior: Managerial objectives in a theory of the firm. Englewood Cliffs, N. J.: Prentice-Hall.

Williamson, O. 1991. Economic institutions: Spontaneous and intentional governance. Journal of Laze, Economics, and Organization, 7: 159-187.

Wooldridge, J. M. 2010. Econometric analysis of cross section and panel data. Cambridge, MA: MIT Press.

Wright, M., Filatotchev, I., Hoskisson, R. E., \& Peng, M. W. 2005. Strategy research in emerging economies: Challenging the conventional wisdom. Journal of Management Studies, 42(1):1-33.

Xu, C., \& Yan, M. 2014. Radical or incremental innovations: R\&D investment around CEO retirement. Journal of Accounting, Auditing, and Finance, 29(4): 547-576. 
Junxiong Fang (jxfang@fudan.edu.cn) is a Professor of Accounting in the School of Management at Fudan University, China. Dr. Fang obtained his $\mathrm{PhD}$ from Fudan University. His main research interests are corporate governance, executive compensation, audit quality, regulatory policies, and financial investment.

Lerong He (lhe@brockport.edu) is an Associate Professor of Management in the School of Business and Management at The College at Brockport, State University of New York. Dr. He is also a distinguished visiting professor in the School of Economics \& Management at Fuzhou University, China. She obtained her PhD from the Wharton School, University of Pennsylvania. Dr. He's main research interests include corporate governance, strategic leadership, new venture strategy, business ethics, and emerging markets.

Martin Conyon (martin.conyon@gmail.com) is the Trustee Professor of Corporate Governance and the Director of Doctoral Program at Bentley University. He is also a Senior Fellow at the Wharton School, University of Pennsylvania and a Fellow at the Institute of Compensation Studies at Cornell University. Dr. Conyon obtained his PhD from University of Warwick, UK. His main research interests are organizations and corporate governance. He has published extensively on topics related to boards of directors, executive compensation, leadership, top management teams, society and ethics.

Manuscript received: March 15, 2016

Final version accepted: October 11, 2017 (number of revisions - 2)

Accepted by: $\quad$ Senior Editor Xiaowei Rose Luo 